IZA DP No. 8407

Labour Market Progression of Canadian Immigrant Women

Alícia Adserà

Ana Ferrer

August 2014

Forschungsinstitut zur Zukunft der Arbeit Institute for the Study of Labor 


\title{
Labour Market Progression of Canadian Immigrant Women
}

\author{
Alícia Adserà \\ Princeton University \\ and IZA \\ Ana Ferrer \\ University of Waterloo \\ Discussion Paper No. 8407 \\ August 2014 \\ IZA \\ P.O. Box 7240 \\ 53072 Bonn \\ Germany \\ Phone: +49-228-3894-0 \\ Fax: +49-228-3894-180 \\ E-mail: iza@iza.org
}

Any opinions expressed here are those of the author(s) and not those of IZA. Research published in this series may include views on policy, but the institute itself takes no institutional policy positions. The IZA research network is committed to the IZA Guiding Principles of Research Integrity.

The Institute for the Study of Labor (IZA) in Bonn is a local and virtual international research center and a place of communication between science, politics and business. IZA is an independent nonprofit organization supported by Deutsche Post Foundation. The center is associated with the University of Bonn and offers a stimulating research environment through its international network, workshops and conferences, data service, project support, research visits and doctoral program. IZA engages in (i) original and internationally competitive research in all fields of labor economics, (ii) development of policy concepts, and (iii) dissemination of research results and concepts to the interested public.

IZA Discussion Papers often represent preliminary work and are circulated to encourage discussion. Citation of such a paper should account for its provisional character. A revised version may be available directly from the author. 


\section{ABSTRACT}

\section{Labour Market Progression of Canadian Immigrant Women*}

We use the confidential files of the 1991-2006 Canadian Census, combined with information from $\mathrm{O}^{*} \mathrm{NET}$ on the skill requirements of jobs, to explore whether Canadian immigrant women behave as secondary workers, remaining marginally attached to the labour market and experiencing little career progression over time. Our results show that the labor market patterns of female immigrants to Canada do not fit the profile of secondary workers, but rather conform to patterns recently exhibited by married native women elsewhere, with rising participation (and wage assimilation). At best, only relatively uneducated immigrant women in unskilled occupations may fit the profile of secondary workers, with slow skill mobility and low-status job-traps. Educated immigrant women, on the other hand, experience skill assimilation over time: a reduction in physical strength and an increase in analytical skills required in their jobs relative to those of natives.

JEL Classification: J01, J61, F22

Keywords: skill assimilation, labour market outcomes of immigrant women, wage gaps, female labor force participation, Canadian migration

Corresponding author:

Alícia Adserà

Woodrow Wilson School

Princeton University

437 Wallace Hall

Princeton NJ 08544

E-mail: adsera@princeton.edu

\footnotetext{
* Individual data used in this study come from the 1991, 1996, 2001 and 2006 confidential files of the Canadian census of population. Access to the data is restricted to the Research Data Centers in Canada. It was provided to the authors under contract with Statistics Canada and the data cannot be released by the authors. Individuals wishing to request access to these data can do so through the website http://www.statcan.gc.ca/rdc-cdr/index-eng.htm. The authors will be pleased to answer questions by researchers on how to contact Statistics Canada.
} 


\section{Introduction and Theoretical Framework}

The existing literature on the employment choices and trajectories of women in immigrant families is divided. A popular account of the labour supply choices of immigrant women highlights their role as secondary (or lower-wage) earners in the household. This explanation relies on traditional views of gender roles within families and argues that recent immigrant women join the labor market largely to support their husbands' investment in local skills - which depreciate upon migration (Long 1980; Baker and Benjamin 1997, Worswick 1999). This view is, however, at odds with findings showing that married immigrant women make labor supply decisions similar to those recently observed for native married women (Blau et al., 2003), who are guided by their own opportunities in the labour market. In this paper we exploit a large sample of immigrant women taken from the restricted files of four Canadian censuses (1991-2006), combining it with information on the skill requirements of the jobs women hold. This paper is the first one to assess the labor market advancement of Canadian immigrant women through the changes in the task content of their occupations -- in line with recent work in labour economics (Acemoglu and Autor 2011). Our findings reveal that the labour market behavior of female immigrants in Canada seems to follow a path of assimilation similar to that of men and that, at best, only relatively uneducated immigrant women in jobs requiring very basic skills may fit the profile of secondary workers (as in Kim and Varanasi 2010).

Economic theory suggests that, within a couple, the need to finance the investment in human capital or local labor skills of the worker with best earnings potential (primary worker) is an important factor that explains secondary worker's participation decisions. As immigrants often have to acquire host-country specific skills upon immigration, it is likely that the patterns of labor force participation of immigrant and native-born secondary workers will differ. This model has been recently challenged by observations of increasing participation of women in the labour market and of their rising role as primary workers in some families (Blau and Khan 2007). ${ }^{1}$ Here we explore whether or not immigrant women behave as secondary workers, and, as such, remain marginally

\footnotetext{
${ }^{1}$ In Canada, the fraction of single-earner couples has plummeted from $46 \%$ in 1976 to $18 \%$ in 2011 , whereas the fraction of couples with wives as primary earners (in the total population) has increased from $8 \%$ to $31 \%$ during the same period.
} 
attached to the labour market only in response to household income shocks and, thus experience little career progression over time. We would expect this to be the case when immigrant men have a higher potential productivity or more easily transferable skills to the host country than their spouses, or if the gender norms within immigrant households do not support a females' labor activity, regardless of the labour market status of the male immigrant.

A large literature of academic and non-academic studies documents immigrant assimilation using different measures of labour market performance (Chiswick, 1978, 1986; Borjas, 1985, 1995, 2013). ${ }^{2}$ Traditionally this work focused on men, partly because labour force decisions of women were more complex and required richer data, and partly because women were considered less economically relevant. Hence, the majority of earlier studies typically looked solely at male immigrants, though a few papers also analyzed the labour market outcomes of immigrant women (Amuedo-Dorantes and de la Rica, 2007; Adsera and Chiswick, 2007; Ferrer and Ridell 2008; Dustmann and Fabri, 2005; Shoeni, 1998; Duleep and Sanders 1993; Beach and Worswick, 1993). Most of these studies that distinguished workers by gender found that, in general, the assimilation patterns of female and male immigrants were different.

Long (1980) was one of the first to suggest that the Family Investment Hypothesis (FIH) could explain this finding. This theoretical framework is founded on the notion that secondary workers support primary workers' investment in human capital and this seems to specifically apply to immigrant households. Since recent immigrant families are more likely to be credit-constrained than native-born families, female immigrants may be more likely to work during the first years in the destination country than similar native-born (in this case Canadian) women. Further, these women may be more likely to work in lower status occupations and experience less upward mobility over time than similar natives. As primary workers (men) improve their labour market outcomes (and financial constraints ease), their spouses’ participation in the labour market should converge to that of similar Canadian-born women. In addition, other researchers argue that the labor market

\footnotetext{
${ }^{2}$ Since the 1990s, some studies report that most recent immigrant cohorts to most major host countries have experienced a significant deterioration in their economic well-being relative to previous arrival cohorts (Borjas 1995; Bell, 1997; Dustmann et al., 2003; Aydemur and Skaterud 2005; Antecol et al, 2006; Clark and Lindley, 2009; Beenstock et al., 2010).
} 
participation of immigrant women with highly educated spouses is more likely to follow this pattern as potential gains from supporting the primary worker's human capital investments are bound to be large (Duleep and Regets, 1999).

This hypothesis has received some attention in the empirical literature of immigrant assimilation. Duleep and Sanders (1993) compare the labor market outcomes of immigrant couples from different origins to the US, and show that the labor force participation of married immigrant women appears to depend on their husbands' investments in local skills. Worswick (1996, 1999) finds that credit constraints significantly affect the labor supply decisions of immigrant families recently arrived to Canada. These studies, however, cannot distinguish the effect of dissimilar work preferences between immigrants and natives from the effect of credit constraints. Baker and Benjamin (1997) use mixed couples (in which one spouse is native-born and one spouse is foreignborn) to separate these two effects by assuming that all immigrants will have the same preferences, but those married to native-born spouses will be less credit-constrained than the others. They find that immigrant women married to immigrant men are more likely to work immediately after migration, and have flatter wage profiles and a lower propensity to undertake country-specific human capital investments than immigrant women married to native-born men. They argue that they are able to eliminate alternative explanations for these patterns and conclude in favour of the family investment hypothesis. However, in implementing a similar strategy for the case of US immigrants, Blau et al. (2003) find that both immigrant husbands and wives work and earn less than comparable natives upon arrival to the US. Further, both spouses show positive assimilation profiles of similar magnitude in labor supply and wages, hence rejecting the predictions of the model for the US.

It is not surprising to find conflicting evidence regarding the labour market outcomes of married immigrant women since immigration policies and institutions for immigrant assimilation vary across destinations. This, in turn, is bound to affect the composition of immigrant flows and the way immigrant families allocate their time. Further, any changes on those institutional features within a country could introduce further changes over time and result in conflicting empirical results. Duleep and Dowhan (2002) analyze longitudinal data and suggest that the theory of women as secondary workers is consistent with the earnings path of immigrant women to the US from earlier cohorts, but not with that of recent cohorts. Kim and Varanasi (2010) use the Current Population 
Survey to replicate the results in Blau et al. (2003) and find evidence consistent with the secondary worker's theory only among immigrant women to the US working in low-status jobs.

We build on this literature to look, first, into the labour force participation and wage progression of recent cohorts of Canadian immigrant women. Second, we focus on the skill content of the jobs they hold to assess their labour market progression, a novel approach within the study of female immigrant assimilation in Canada and in line with recent work by Autor and Handel (2013). Third, besides employing multiple measures to evaluate the labor market assimilation of migrant women, this paper contributes to the literature by looking at the most recent immigrant cohorts with more detailed data than previous studies did. Much has changed in the Canadian labour market during the 1990s and 2000s, particularly in regards to immigration policy and, as a result, the composition of the immigrant pool has evolved, most notably regarding the educational attainment of immigrants (Ferrer, Picott and Riddell, 2014). Therefore, we do not necessarily expect to replicate previous results in the literature with the dataset employed here. In addition, the use of confidential Census data, with more complete individual information than in the publicly available files, enables us to better control for immigrant heterogeneity in an array of dimensions. For instance, we are able to include both linguistic proximities between origin and destination countries and degrees of labour force attachment among women in their countries of origin, to better understand the influence of the source country on the outcomes of immigrant women.

The next section discusses the methodology and presents the data. Section 3 shows the results on labor force participation, wages and skill assimilation. Section 4 discusses the robustness of the results, and the final section concludes.

\section{Methodology and Data}

Our analysis of the labour market assimilation of immigrant women follows pioneer work by Borjas (1985) that relies on multiple cross-sectional data to disentangle the cohort and entry effects from immigrant outcomes. Because we are interested in the outcomes of married immigrants, we distinguish four different types of families in our analysis and include separate entry-cohort effects for each immigrant spouse. We estimate the following type of regression to compare the performance of immigrant women to those of the native-born 


$$
Y_{i t}=X_{i t} \beta_{1}+\sum_{h=I, N B} \sum_{t} \sum_{k} \tau_{k t} C_{i k}^{W h} * t+\sum_{w=I, N B} \sum_{t} \sum_{k} \tau_{k t} C_{i k}^{H w} * t+\gamma t+\varepsilon_{i t}
$$

where the dependent variable $\left(Y_{i t}\right)$ is a measure of labour market performance of woman $i$, in survey year $t ; X_{i t}$ is a vector of individual/household characteristics including age, age squared, fertility indicators, education, husband wage, province and city of residence, and a measure of linguistic proximity of mother tongue to local language; $C_{i k}{ }^{\text {Wh }}, C_{i k}{ }^{\mathrm{Hw}}$ are indicators for different $k$-immigrant arrival cohorts of immigrant wives/husbands, which we interact with the indicator for survey year $(t)$ to track the evolution of different cohorts over time. Cohorts are defined over five years (e.g. the '91 cohort includes individuals arriving between 1986 and 1991). To differentiate mixed couples, cohort effects vary depending on whether the husband/wife $(h / w)$ of the immigrant is him/herself immigrant or Canadian born. The coefficients for the cohort-time indicators $\tau_{k t}$ are the key parameters of interest. This model allows us to focus specifically on immigrants in immigrant couples and compare our results with those of Baker and Benjamin (1997). In our robustness analysis, we also include gender differences in labor force participation in the country of origin to control for cultural differences in preferences for female employment.

Our basic measures of labour market performance $Y_{i t}$ include labour force participation and wages. However, a distinctive feature of our analysis is a focus on occupational skills. The type of skills required in jobs women hold is an important dimension to consider because according to the traditional view on gender roles, secondary workers will increase participation only temporarily to support their partner's investments in human capital. This implies that no real career progression is to be expected among women (Kim and Varanasi, 2010). However, if immigrant women are not secondary workers, we are likely to observe some professional advancement, as measured by changes in the occupational skills their jobs entail. Occupational skills might track women's assimilation better than wages, as some career positions (that require high skills) are initially lower paid than some unskilled ones. Hence in alternative specifications of the model, $Y_{i t}$ is a measure of occupational skills.

This focus on skills rather than on occupation is significant. Typically, most job changes (and their accompanying wage responses) involve substantial adjustments in skill requirements, but might not result in a change in the occupational category, particularly when measured broadly (Autor and Handel (2013). The occupational matching literature uses detailed information in occupation 
databases - either the Dictionary of Occupational Titles (DOT) or the Occupational Information Network (O*NET) - to derive a small set of fundamental skill requirements for each job. The skills we consider here come from Imai et al (2011) and are derived from the O*NET. These include two indexes for cognitive skills (social and analytical) and three indexes for manual skills (fine motor skills, physical strength, and visual skills). To facilitate interpretation of the data, the detailed information in the $\mathrm{O}^{*} \mathrm{NET}$ is summarized by constructing a low-dimensional vector of occupational characteristics using Principal Component Analysis (PCA). ${ }^{3}$ The result is a vector of skills necessary to perform the job tasks associated with each 4-digit occupational category using the O*NET. The factor analysis uses as weights the distribution of the skill distribution of the Canadian working population; hence a unit of the skill score (with mean zero) can be interpreted as one standard deviation in the skill distribution of the Canadian population.

The inclusion of a measure of linguistic proximity is another distinctive feature of our analysis. As suggested by previous research, both fluency in the language of the destination country and the ability to learn it quickly will influence an immigrant's success in destination countries' labor markets (Bleakley and Chin 2004; Chiswick and Miller 2002, 2010; Dustmann and van Soest 2002). Hence, variation in linguistic proximity can be used to further determine ease of access to labour market opportunities. However, the Canadian Census has no measure of linguistic fluency which would help to undertake this type of analysis. As a proxy of fluency, we use the measure developed in Adsera and Pytliková (2014) based on information from the encyclopaedia of languages Ethnologue (Lewis, 2009). The Linguistic Proximity index ranges from 0 to 1 depending on how many levels of the linguistic family tree the languages of both the destination and the source country share. Thus, the linguistic proximity index equals 0 if two languages do not share any level of the linguistic tree; 0.1 if two languages are only related at the most aggregated linguistic tree level, e.g. Indo-European languages; 0.25 if two languages belong to the same first and second- linguistic tree level, e.g. Germanic languages; 0.45 if two languages share the same first up to third linguistic tree level, e.g. Germanic North languages; and 0.7 if both languages share all four levels of linguistic tree family, e.g. Scandinavian East (Danish, Norwegian and Swedish) and finally the index equals 1 if

\footnotetext{
${ }^{3}$ In the PCA, factor loadings are calculated so that variation of the data explained by the constructed variable is maximized. A detailed description of the procedure can be found in Imai et al. (2011).
} 
both languages are the same. The measure provides a more detailed metric of proximity between any pair of languages and provides a far better adjusted and smoother indicator of proximity than the standard dummy for common language used in most of the literature. We match this measure to an indicator of the individual's place of birth contained in the Canadian census. Adsera and Pytliková (2014) include a variety of ways to measure linguistic proximity among countries depending on whether they employ only the first official language, any of the official languages or the most commonly spoken language in each country (which may not even be official). For our analysis we have selected the broadest index that measures the minimum distance between either English or French (the two official languages in Canada), and any of the official languages in the country of origin. This means that our reference group (of common language) includes individuals arriving from countries where English or French is an official language and it is composed by immigrants coming from India, Kenya, Cameroon or Madagascar as well as from the US or France. Hence, given the large heterogeneity of this group, our measure of linguistic proximity might not be able to fully separate the effect of language from other characteristics such as visible minority status. In regressions not shown here, however, we add controls for characteristics of the country of origin, which would account somehow for the influence of culture or ethnicity on labour market outcomes. The results regarding the variables of interest do not change substantially and are available upon request.

The rest of our data comes from the restricted individual files of the Canadian Census (1991 through 2006). Previous Canadian studies used public-use Census 1981 and Census 1991 (Worswick, 1996, 1999) or the Survey of Consumer Finances, 1986 and 1991 (Baker and Benjamin, 1997). The use of the confidential Census files increases the level of information on key variables such as country of origin (for immigrants) or fertility in comparison to publicly available data. The large samples contained in the restricted Census files also help to reduce the presence of attenuation bias. The confidential files offer comprehensive information on individual labour market outcomes, occupation, country of birth, year of arrival and mother tongue. For each woman we compile relevant information regarding other members of the household, including spouse and the number of children, to obtain detailed measures of fertility based on the number of children in the household and the spouse's immigration and labour market characteristics. Our indicators of fertility include the number of births, the age of the children, and the mother's age at different births. The inclusion of these variables can potentially control for interruptions in labor force experience over a woman's 
life cycle. Childbearing is an important ambit in which immigrant and Canadian-born females are likely to diverge (Adsera and Ferrer, 2014).

We select a sample of married (or common-law, CL) women aged 18 to 45 for our analysis, and only include immigrant women who immigrated as adults - at age 18 or after. This age restriction directs the attention of the paper to the main reproductive years of women and renders our measures of fertility more reliable since we use the number of children living in the household rather than the number of births. The immigrant selection allows us to focus on the assimilation of younger (adult) immigrant women, which constitute the majority of the immigrants. ${ }^{4}$ Most adult immigrant women are married at the time of arrival as marriage is a requirement for spousal visa, the most common visa among female immigrants. We exclude aboriginal individuals, since their analysis presents a very different set of challenges. In order to reduce computing time to a reasonable length, from each census we select all immigrant women plus a 20 percent random sample of Canadian born women in the same age range and weight the observations accordingly. Our final sample contains over 800,000 observations.

Table 1 presents summary statistics by family type. Immigrant women are older and more likely to have university education than natives. Conversely, immigrant women are less likely to participate in the labor market and work fewer hours on average. With regard to the skill requirements of the jobs women hold, immigrant women in immigrant couples have the highest strength and motor scores and the lowest analytical (or quantitative) and social (or interpersonal) scores among all married women, all characteristics of low status occupations. Immigrant women in immigrant couples work in occupations that require social and analytical skills 0.10 and 0.13 standard deviations, respectively, below the average Canadian worker (both men and women pooled together). Their motor and strength skill requirements are also below those required for the average Canadian worker, but are the highest among married women. In contrast, the average skill requirements in jobs held by immigrant women in mixed marriages involve social and analytical skills that are on average 0.26 and 0.09 standard deviations above the mean Canadian worker.

\footnotetext{
${ }^{4}$ The behavior of child immigrants is likely very different from that of adult immigrants (Adsera and Ferrer, 2014; Mayer and Riphalm, 2000), particularly since they do not confront the same trade-offs between work and family at arrival and they are likely more assimilated to Canadian norms through schooling.
} 
Moreover their motor and strength skill requirements are 0.36 and 0.30 standard deviations below that of the average Canadian worker. Figure 1 shows the full distribution of analytical and physical strength skills by family type. ${ }^{5}$ A positive index indicates either more physical strength or analytical demands than the job held by the average worker. Finally, among immigrants, linguistic proximity is the lowest for women in immigrant couples. Around $40 \%$ of these women come from countries where either English or French is an official language - versus 60\% of immigrant women in mixed marriages - while for a large fraction of immigrant women (23\%) none of the official languages in their country of origin has any common branch in the linguistic tree with either English or French.

\section{Regression results}

\subsection{Labour force participation}

The starting point of previous papers looking into the labour market outcomes of immigrant women is to examine whether or not, in accordance to characterization of female employment as secondary work, immigrant women with immigrant spouses are more likely to participate in the labor market upon arrival than the native-born (or the immigrants married to native-born) and whether their participation declines with time in Canada. Another prediction within this framework that needs to be contrasted empirically is that, as secondary workers, immigrant women are more likely than other women to enter low-status job that they eventually leave as their spouses assimilate.

We first estimate a specification of equation (1) with a logit model where the dependent variable is a binary indicator of labour force participation. The results are presented in Table 2 as odd ratios: the difference in the probability of a woman's participating relative to similar native-born women with native-born partners. The first panel shows the odds ratio of participating in any type of job for all married women and the second panel only for university-educated women. Interest in the latter group arises because Canadian immigration policy placed a strong emphasis on formal education during the 1990 and early 2000s. Although this typically applied to the main applicant, generally a man, it resulted as well in a high fraction of educated spouses (Sweetman and Warman, 2009). Hence, recent cohorts of immigrant women to Canada have high levels of education relative

\footnotetext{
${ }^{5}$ Note that skills here measure the skills involved in performing the job, not the actual skills of the worker.
} 
to the native-born and are deemed more likely to participate consistently in the labour market than previous cohorts.

Some recent studies show an association between factors such as female labour force participation rates in the home country and immigrant women's labour market decisions in the host country (Frank and Hou, 2013; Blau et al. 2011; Fernández and Fogli 2009). In separate regressions, not shown here, we include country of origin characteristics as additional controls in the regressions (fraction of individuals with higher education, female labour force participation ratio and GDP). The results from those regressions are qualitatively similar to those presented here, with slightly higher levels of participation than when these characteristics are omitted. Those results are available upon request. We prefer to show here the results for the average immigrant woman in each cohort since the focus of this paper is not on cultural differences among immigrants.

All cohorts of immigrant women in the sample show lower levels of participation than the Canadian born at arrival, with participation rising steadily (rather than declining) over years spent in Canada. For instance, the odds ratio of immigrant women with immigrant partners participating in the labour market during the first 5 years in Canada - relative to a native-born woman - was 0.346 for the cohort arriving between 1991 and 1996. After 15 years in the country, the participation of this cohort of immigrant women relative to natives had increased to 0.737 . This pattern looks very similar for immigrant women in immigrant couples and those in mixed partnerships. Although the first group shows somewhat lower levels of participation than those in mixed couples - particularly for later arrival cohorts - participation in the labour market evolves at similar paces for both groups. This means that neither group of immigrant women seems to behave as predicted for secondary workers. This is in sharp contrast with results in Baker and Benjamin (1997) who found that hours of work declined with time in Canada for previous immigrant cohorts. We observe, for this more recent sample of women, an increase in participation similar to that experienced by immigrant men during their assimilation process (Borjas, 1995; Aydemir and Skuterud 2005) or by immigrant women in the US and Germany (Blau et al. 2003; Basilio et al. 2009).

One plausible explanation for the difference between our findings and those of previous Canadian literature is that the newest cohorts of immigrant women are more committed to the labour market than previous cohorts. To study this, we look at how participation in the labour market 
evolves for immigrant women entering low-skill occupations. We expect that immigrant women only seeking temporary attachment to the labour market to support family settlement in Canada are more likely to enter low-skill occupations (Kim and Vanarasi, 2010). Low-skill jobs are defined here as those requiring skills at the bottom $25 \%$ of the analytical skill distribution or at the top $25 \%$ of the physical strength skill distribution. ${ }^{6}$ Hence, the dependent variable is one if a woman participates in a low-skill job and zero otherwise. If immigrant women are entering these occupations merely to support their husbands while they update their human capital, we would expect to see high levels of participation in these jobs - at least initially - relative to the native-born. The first panel of Table 3 shows the results of this exercise. Clearly all immigrants participate in low-skill jobs upon entry to Canada relatively more than similar native-born married women. Immigrant women in mixed couples show rather flat (in low-analytical jobs) or slightly declining (in high-strength jobs) profiles of participation with years in Canada, with some cohorts participating at higher levels than others. Conversely, immigrant women with immigrant partners show a relative increase in participation in low-skilled jobs over time. While a declining relative participation pattern could have been difficult to interpret since it could be due to women either retiring from the labour force or moving up into more skilled positions, the increasing pattern suggests that immigrant women either remain or continue to enter in low-skill jobs at a much higher rate than native-born women do.

One way to account for this result is that the type of immigrant woman entering either high- or low-skilled jobs might be substantially different from the native-born entering those jobs. In particular, since immigrant women are better educated (as seen in the descriptive statistics) and presumably more career-oriented, they may not be inclined to leave the labour force. We repeat the analysis with the subsample of university-educated women to compare women with more similar career expectations. These results are shown in the second panel of Table 3. Among universityeducated immigrants, those in mixed couples are between 1.6 and 2.8 times more likely to participate in occupations requiring low analytical skills and between 1.1 and 1.4 times more likely to participate in occupations requiring high physical strength than similar natives. There is some evidence of convergence over time in jobs requiring high levels of strength. However, for those in

\footnotetext{
${ }^{6}$ Results are similar if we use instead jobs requiring low social skills (at the bottom $25 \%$ of the social skill distribution) or high fine motor or visual skills (at the top $25 \%$ of the corresponding skill distributions) to define a low-skill job.
} 
immigrant couples, there is strong evidence that participation in low-skill jobs rises with time in Canada, particularly in jobs requiring low analytical skills. The likelihood of participating in those jobs is more than 3 times higher for these immigrant women than for the native-born, even 10 and 15 years after migration. ${ }^{7}$

The above results indicate that among the university-educated a much larger fraction of immigrant women than Canadian-born women are placed in low-skilled occupations regardless of time since arrival. Because our data is not longitudinal, we cannot readily interpret this finding as portraying highly-educated immigrant women “trapped” in relatively low-skilled positions. It could be the case that some of these educated immigrants start in low-skilled jobs and move up to higher skill positions with time, but are replaced (in the aggregate) by immigrant women of the same arrival cohort who were not working before that time. The Census data does not allow us to explore this scenario. We do observe that the fraction of university-educated women in highly-skilled occupations increases over time for most cohorts, suggesting that this could indeed be the case. In separate estimates that focus on the very short run - the first five years after migration, we find that educated women enter low-skilled positions much faster than the high end of the labor market. After one year in Canada, the odds that a university-educated immigrant women is in a low-skill job relative to similarly educated native-born women move up from around 1.3 at arrival to 2, whereas the odds ratio of holding a high-skilled job remains stable around 0.6 and only slowly increase to 0.8 after five years in Canada (See figure 3).

\subsection{Wage assimilation}

Another important dimension along which to study the labour market outcomes of immigrant women is wages (Duleep and Dowhan 2002; Basilio et al.2009). Among secondary workers who enter the labour market in response to income shocks, no significant wage advancement is expected as these intend to be temporary positions. Hence, under this framework, the wage assimilation of immigrant women is expected to be relatively flat.

\footnotetext{
${ }^{7}$ Although the number of university-educated individuals working in low-skill analytical jobs is not large - just under 20,000 in our sample - it is comprised mostly by immigrant women in a 3 to 1 ratio.
} 
Table 4 shows the difference in log wages between different cohorts of immigrant women and similar native-born women from an OLS regression of equation (1) where log wages are the dependent variable. Result in column (1) show that married immigrant women have low initial earnings, between 20 and 50\% lower, but gradually converge to those of the native-born. The convergence seems to be slower for more recent cohorts. The inclusion of additional controls tends to reduce wage differences between immigrants and the native-born, but preserves the assimilation patterns discussed above. ${ }^{8}$

A substantial part of the gap seems to be related to the skills required in the jobs women hold. Controlling for the skills required (column 2), the wage gap of recent cohorts decreases, except for the 2001 entry cohort which arrived at the time of the IT bust in Canada. Wages are generally higher in jobs requiring high levels of social, motor and analytical skill and lower in jobs requiring high levels of physical strength and visual skills. As expected, closer proximity to English or French results in higher wages as indicated by the large negative coefficients when the mother tongue of the immigrant has none or only one branch of the linguistic tree in common with the official Canadian languages.

Next, we use a two-step Heckman correction model to estimate the wage progression of women by taking into account their selection into the labour force. As instruments for the first stage regressions, we include the number of children in the household and the female/male ratio of labour force participation in the country of origin either at the time the woman immigrated to Canada or when the woman was 18 years of age for the Canadian-born. ${ }^{9}$ Results are shown in column (3). First stage estimates and the test of interdependence of equations are presented in the on line appendix. Our instruments are all strongly significant, with fertility indicators and the gender labour force ratio at home being, respectively, negatively and positively related to women's labor force participation. The Chi2 test of independence of equation confirms the endogeneity of participation decisions. Accounting for selection generally reduces the wage gap between immigrant and native-born

\footnotetext{
${ }^{8}$ We find this increasing wage profiles even when we restrict the sample to women working in low-status jobs (those that require low levels of analytical skills), which are the jobs secondary workers are expected to enter. Results are available from the authors upon request.

${ }^{9}$ The measure of female labour force participation ratio in the country of origin comes from Frank and Hou (2013).
} 
women, particularly during the first years but produces similar estimates after 15 years in Canada than those in column (2). This could reflect the diminishing influence of country of origin culture with time spent in Canada. The observed reduction in the wage gap is also particularly strong for the 2001 cohort. Overall, the patterns observed in columns (1) to (3) consistently confirm strong wage assimilation with years in Canada. ${ }^{10}$

Columns 4 and 5 in table 4 show results for the subsamples of non-university and universityeducated women respectively. For ease of exposition we also present these estimated coefficients in Figure 4. The immigrant native-born wage gap at arrival is higher for the university-educated than for non-university educated - around 40 to $50 \%$ for recent cohorts -, but the rate of wage progression is faster for this group as well: wage differences close down to $15 \%$ after 15 years in Canada. In contrast, among the non-university educated, initial wage gaps stand at around 20\%, but they disappear within the 15 year range. ${ }^{11}$

Given the high levels of formal education of recent immigrant women compared to those of the native-born, the observed low initial pay is unlikely the product of less skills, but could be due to difficulties in transferring them to the new environment. Among these hurdles, language barriers are a likely candidate. Estimates in columns (4) and (5) show that the penalties associated with linguistic distance (low levels of linguistic proximity) are higher for the subsample of university-educated immigrants (relative to similarly educated native-born) than for immigrants with lower educational attainment.

To explore this issue in more detail, Table 5 displays results from a model that includes the interaction between different degrees of linguistic proximity and university education for the sample of all married women. Cells in each row present the wage gap of immigrants with a given LP $<1$ relative to similarly educated immigrants with English or French as one of the official languages in

\footnotetext{
${ }^{10}$ In additional regressions not shown here, we use a variety of instruments of fertility including the number of children before immigration and age at first birth, with and without including occupational skills in the regression. The results albeit at different levels - show the same steep assimilation pattern described in model (3).

${ }^{11}$ Although not presented here, estimates of cohort effects on wages correcting for selection are similar to those presented above.
} 
their countries of origin. ${ }^{12}$ Results show that decreasing linguistic proximity is correlated with lower wages, particularly among the highly educated. The downward effect of linguistic distance on wages is most noticeable at the low end of the spectrum, for values of linguistic proximity equal to 0.1 and 0 (when at most either one branch of the linguistic tree or none is shared between the two languages). Immigrants without university education experience only a small wage penalty when their language proximity index is 0.1 and 0 - their wages are respectively $2.1 \%$ and $4.6 \%$ lower than those of similarly educated immigrants with $\mathrm{LP}=1$. Immigrants speaking languages from linguistic groups of medium linguistic proximity to French or English (index 0.45 and 0.25 ) even experience small wage premiums. ${ }^{13}$ University-educated immigrants experience larger penalties relative to similarly educated immigrant women arriving from countries with English or French as official languages. The wages of immigrant women speaking languages closely related to French or English are between $5 \%$ and $6 \%$ lower. Those immigrants whose language is only distantly related to the official languages in Canada (index 0.1) suffer a wage reduction of $18 \%$ and those whose language is not at all connected to either French or English face a wage gap of 11\%. These results suggest that for immigrant women linguistic proximity plays an important role in the transfer of skills embodied in formal education.

\subsection{Skill assimilation}

Our previous results indicate that (a) immigrant women do not leave the labour force - not even low-skill jobs -by the time their partners should have presumably assimilated, and (b) show important wage progression over years in Canada. Rather than being secondary workers, immigrant women seem to be attached to the labour market, pursuing careers of their own in agreement with the observed patterns of increasing participation and wage assimilation. In this context, an analysis of job-skill mobility could be more informative than that of participation or wages, or at least complementary, to evaluate the progress of immigrant women. These women might be doing

\footnotetext{
${ }^{12}$ To compare individuals with university education to those without it, we would need to add the estimated coefficient for the university dummy ( 0.466 significant at 1 per cent)

${ }^{13}$ With respect to English or French, in our sample, the linguistic index with a value 0.45 generally corresponds to most Germanic languages and the index with a value of 0.25 to Scandinavian languages. Individuals born in these countries may likely formally study foreign languages, particularly in French and English, which might facilitate their linguistic assimilation when migrating.
} 
considerable "occupational jumping" from initial low-skilled jobs to higher skilled jobs. As a consequence, a significant change in job-skills may not involve significant shifts in participation or even wages gains if a woman is switching to a new job requiring a different set of skills.

We study patterns of skill mobility among immigrant women, using the model in equation (1) where the dependent variable is the measure of the skill index in the job they hold. Our purpose is to assess whether there is mobility in the skills required for the jobs immigrant women perform. Table 6 shows the coefficients for skill progressions of different cohorts with years since arrival. For clarity, these are also represented in Figures 5 and 6 for the progression in analytical and strength skill, respectively. Each Figure presents results for the mobility of immigrant women in mixed and non-mixed couples for the basic model in panel (a) and for university-educated in panel (b).

Immigrants generally work in jobs requiring more (less) strength (analytical) skills. Those in mixed couples are "closer" to the native-born than those in immigrant couples and experience progression over time in both skill dimensions. The patterns of skill mobility for those in immigrant couples, however, are surprisingly flat, both in terms of strength and analytical skills. A somewhat surprising result is the relative absence of cohort effects in analytical skill progression, with cohorts starting mainly at similar levels of skills over time. By contrast estimates show strong cohort effects for the evolution of strength skills, which are significantly increasing for each successive cohort of immigrant women in immigrant couples.

The above results suggest that the majority of immigrant women experience little career progression as measured by the skills embodied in the jobs they take. This could be interpreted as the result of low attachment to the labour force that follows the patterns of secondary workers. However, they are puzzling when taken together with the patterns of labour force participation and wage mobility examined before.

One possibility could be that the aggregate results are masking different patterns for different types of women. As mentioned in the introduction, the Canadian immigration system has undergone considerable changes during the 1990s and 2000s that have affected the educational composition of immigration. It is plausible that the career expectations and labour force attachment of immigrant women may be very different depending on their education. To explore this issue in more detail, we repeat the analysis for a subsample of university educated women in panel (b) of figures 5 and 6. 
The picture for educated immigrants is very different. Now we see a more dramatic trend in skill progression. The amount of analytical skills required by the jobs these immigrants hold increases over time, but more importantly there is a significant reduction in the amount of strength skills required in these same jobs. Educated immigrants with immigrant spouses from the 1996 cohort start in jobs requiring levels of skills that are 0.3 standard deviations higher than those required for the average Canadian-born woman job. After 5 years in Canada, these women hold jobs that require strength levels only 0.15 standard deviations above the average. This is a remarkable change considering the flat profiles that we observe for the average immigrant woman. This suggests that it is mainly immigrants with no post-secondary education who remain in low status jobs - as measured by the levels of skills jobs require.

\section{Robustness}

\subsection{Immigrant husbands}

Immigrant women who behave as secondary workers participate in the market to attenuate household income shocks that occur during the first years after immigration. Among recently arrived immigrants, a working wife may allow men more time to search of a suitable job or to train and to acquire local human capital. If this strategy is successful, we might observe these immigrants assimilating better in the labour market than others. We test the extent to which the labour force outcomes of immigrant women can be associated with this type of behavior by looking at the labour outcomes of their husbands. In particular, we use the same methodology as before to examine the wage and skill progression of the male immigrant married to the immigrant women in our sample, and take into account whether or not the wife participates in the labour market. Results for male wages and skills are shown in figures 7 (a) and (b).

Men whose wives participate in the labour market show almost identical labour market progression - both in terms of wages and required skills - than the average immigrant. In both cases wage gaps with respect to natives are reduced by half by the time these men have been in Canada between 15 and 10 years. Yet, immigrants whose spouses work start at lower wage levels and hence they do not reach similar levels of wage assimilation within the same period. Although far from being a conclusive test, this result adds to the evidence that immigrant women seem to pursue their 
own careers rather than enter the labour market as a result of income shocks associated with immigration.

\subsection{Cultural preferences regarding the labour market}

The distinction between immigrant women in either immigrant or in mixed partnerships is intended to control for differences in immigrant cultural preferences regarding participation and to focus on the effect of income shocks on female labour market attachment (Baker and Benjamin, 1997). Of course, this is not a perfect measure since there is selection into inter-marriage. Some paper such as Cobb-Clark and Crossley (2004) or Basilio et al. (2009), Cohen-Goldner et al. (2009) are able to use information on the time of marriage to partially correct for this. However, the majority of the literature (as well as this paper) is limited by datasets that do not contain such information and assumes that immigrant couples immigrated together. This could bias the estimates if those marriages took place after arrival as a result of assortative matching. Table 1 indicates that immigrant women in mixed partnerships are more educated and have closer linguistic proximity to the native-born than other immigrant women, which suggests that they are not a good control group for labour force preferences. These human capital advantages can help them land better jobs, but also make them more likely to marry native-born individuals and here we cannot distinguish the two effects. As a result it is difficult to interpret the results for immigrant women in mixed partnerships or to argue we have a causal effect, (as we do not). In an alternative specification, we include in our models a measure of the gender labour force participation ratio at the country of destination measured at the time of immigration as a covariate. Previous research has found it to be associated with labour market outcomes of immigrant women at destination countries (Frank and Hou, 2013). The variable is strongly significant, but its inclusion does not change our participation results qualitatively. Note this is not a major concern for immigrant couples, since the majority of immigrant women are married at arrival (75\%). However, we also rerun our models for the subsample of immigrant women who arrived before their partners (and presumably were not married

at arrival) and find no significant differences in results for immigrant couples. Estimates are available upon request.

\subsection{Age cohort across census years}


One concern with cohort analysis regards the adequacy of the reference group (native-born women married to native-born husbands, aged 18 to 45), which changes over time as native-born women age out of earlier census and are replaced by women from a younger cohort in recent census. We have repeated the analysis using a single age cohort of women - those who were 18 to 24 in 1991 - to keep the age effects constant through the census years. All our results are robust to this consideration and are available upon request.

\subsection{Differences in incentives to support husbands’ investment in local human capital}

As suggested by Duleep and Regrets (1999), immigrant women with educated partners have potentially more to gain from supporting their husbands' investment in local skills. It is plausible that patterns of secondary work can be more prevalent among these women than for the average immigrant. We consider the subsample of women married to educated husbands (those with postsecondary education) to examine this possibility. In general, we do not see much difference in participation profiles between the two groups, either in levels or evolution. Immigrant women married to educated immigrant husbands also show increasing levels of participation with years since migration in low analytically skilled jobs, rather than higher and declining levels over time. Further, the patterns of wage assimilation of women married to educated immigrant husbands and those of women married to non-educated immigrant husbands are alike. Finally, the evolution of analytical skills used in the jobs held by the subsample of immigrant women married to educated immigrant husbands is also similar to that of all immigrant women (See figures 1 and 2 in the on line appendix).

\section{Conclusion}

Our results show that immigrant women have participation profiles, and display advancement in wages and in the skills required in their jobs, that are not consistent with those expected from secondary workers. These women significantly increase participation levels and experience wage gains over time. Educated women also experience significant skill progression with years in Canada. These results seem to contradict the basic predictions of a model where immigrant women are secondary workers who enter the labour market in response to the income shock brought by the skill depreciation of their husbands in their new location and are at odds with findings for previous cohorts of Canadian immigrant women. These general patterns, however, fit with recent evidence in 
the US (Blau et al., 2003 among other), showing that married immigrant women make labor supply decisions similar to those recently observed for native married women and are robust to a variety of alternative specifications. Further analysis by educational attainment suggests that most labour market progression occurs for immigrant women with university education. Despite starting with very low wages and high levels of participation in low-skilled jobs, there is evidence of rapid wage gains and somewhat slow job-skill progression for these immigrants. However, despite the observed labour market assimilation the gap between immigrants and the native-born does not close even after 20 years in Canada.

One of the main changes brought about by the Canadian immigration policy reform during the 1990s and 2000s is the increase in the fraction of female immigrants with post-secondary education. Their share went up from $35 \%$ to $54 \%$ over the period1991-2006, while the corresponding proportion among native-born women only rose from $31 \%$ to $42 \%$. We believe that this shift in the composition of immigrant women might have been responsible for the observed change in labour market attachment as well as wage and skill progression of immigrant women portrayed here. 


\section{References}

Amuedo-Dorantes, C. and De La Rica, S. (2007), Labour Market Assimilation of Recent Immigrants in Spain. British Journal of Industrial Relations, 45(2), pp.257-284.

Antecol H, Kuhn P and Trejo S (2006) Assimilation via Prices or Quantities? Sources of Immigrant Earnings Growth in Australia, Canada and the United States. Journal of Human Resources 41(4), pp. 821-840

Adsera, A. and Chiswick, B. (2007) “Are There Gender Differences in Immigrant Labor Market Outcomes across European Countries?” Journal of Population Economics, 20(3), 495-526.

Adsera, A. and Ferrer, A. (2014) "Fertility Adaptation of Child Migrants to Canada, Population Studies, 68(1), pp. 65-79..

Adsera, A. and Pytliková, M. (2014) “The Role of Languages in shaping International Migration”, Economic Journal (forthcoming).

Autor, D and M. Handel (2013) "Putting Tasks to the Test: Human Capital, Job Tasks, and Wages", Journal of Labor Economics, 31(2), pp. S59-S96

Acemoglu, Daron and David Autor. 2011. "Skills, Tasks and Technologies: Implications for Employment and Earnings.” In Handbook of Labor Economics Volume 4 part B, edited by Orley Ashenfelter and David E. Card, 1043-1171Amsterdam: Elsevier.

Aydemir, A. and Skuterud, M. (2005) "Explaining the Deteriorating Entry Earnings of Canadian Immigrant Cohorts: 1966-2000”, Canadian Journal of Economics, 38(2), pp. 641-72.

Basilio, L., T. K. Bauer, M. Sinning, (2009) “Analyzing the labor market activity of immigrant families in Germany”, Labour Economics, Vol.16 (5), pp. 510-520

Baker, M. and Benjamin, D. (1997) “The Role of the Family in Immigrants’ Labour Market Activity: An Evaluation of Alternative Explanations” American Economic Review 86, pp 705-27.

Beach, C. and Worswick, C. (1993) "Is there a Double Negative Effect on the Earnings of Immigrant Women?” Canadian Public Policy 19: 36-53. .

Beenstock, M. B. Chiswick and A. Patiel (2010) “Testing the Immigrant Assimilation hypothesis with Longitudinal data” Review of Economics of the Household, vol.8(1), pp. 7-27

Bell BD (1997) The Performance of Immigrants in the United Kingdom: Evidence from the GHS. Economic Journal 107: 333-345

Blau, F. , L. Kahn, J. Moriarty, and A. Souza (2003): "The role of the family in immigrants' labormarket activity: An evaluation of alternative explanations: Comment," American Economic Review, 93(1), 429-447.

Bleakley H. and A. Chin (2004) "Language Skills and Earnings: Evidence from Childhood Immigrants.” Review of Economics and Statistics 84 (2): 481-496.

Borjas, G.(1985) "Assimilation and Changes in Cohort Quality Revisited: What Happened to Immigrant Earnings in the 1980's?" Journal of Labor Economics 3, pp. 463-89.

(1995) "Assimilation, Changes in Cohort Quality Revisited and the Earnings of Immigrants" Journal of Labor Economics 13: 201-45. 
(2013) "The Slowdown in the Economic Assimilation of Immigrants: Aging and Cohort Effects Revisited Again", NBER Working Papers 19116

Bratsberg, B. and O. Raaum (2004) Identifying Earnings Assimilation of Immigrants under Changing Macroeconomic Conditions. Scandinavian Journal of Economics 106: 1-22

Chiswick, B. R. (1978) The Effect of Americanization on the Earnings of Foreign-Born Men. Journal of Political Economy 86(5): 897-922.

1986, “Ìs the New Immigration Less Skilled Than the Old?” Journal of Labor Economics, 4(2):168-192

Chiswick, B. and P. Miller (2002) "Immigrant Earnings: Language Skills, Linguistic Concentrations and the Business Cycle.” Journal of Population Economics 15(1): 31-57.

Chiswick, B. and P. Miller (2010) "Occupational Language Requirements and the Value of English in the US Labor Market.” Journal of Population Economics 23(1): 353-372.

Clark, K., \& Lindley, J. (2009). Immigrant assimilation pre and post labour market entry: Evidence from the UK labour force survey. Journal of Population Economics, 22(1), 175-198

Cobb, D. and Crossley, C. (2004) “Revisiting the Family Investing Hypothesis” Labour Economics 11, pp.373-93

Cohen-Goldner, S., C. Gotlibovski, and N. Kahana (2009): "A Reevaluation of the Role of Family in Immigrants' Labor Market Activity: Evidence from a Comparison of Single and Married Immigrants," IZA Discussion Paper, 4185.

Duleep, H., and D. Dowhan (2002) "Revisiting the family investment model with longitudinal data: The earnings growth of immigrant and US-born women." IZA working paper \# 568

Duleep, H. and M. Regets (1999) "Immigrants and human-capital investment”, The American Economic Review, 89(2), pp:186-191

Duleep, H. and Sanders, S.(1993) “The Decision to Work by Married Immigrant Women” Industrial and Labor Relations Review 46: 677-90.

Dustmann, C. and A. van Soest (2002) "Language and the Earnings of Immigrants." Industrial and Labor Relations Review 55 (3): 473-492.

Dustmann C and Fabbri F (2005) "Gender and Ethnicity: Married Immigrants in Britain”, Oxford Review of Economic Policy, vol.21(3), pp. 462-84.

Fernández, R., and A. Fogli. (2009). "Culture: An Empirical Investigation of Beliefs, Work, and Fertility." American Economic Journal: Macroeconomics. Vol. 1. No. 1. p. 146-177.

Ferrer, A.M., D. Green, C. Riddell (2006), “The Effect of Literacy on Immigrant Earnings”, The Journal of Human Resources vol. 41(2) p. 380-410

Ferrer, A., G. Picott and C. Riddell (2014), "New Directions in Immigration Policy: Canada’s Evolving Approach to Immigration Selection”, forthcoming International Migration Review

Ferrer, A.M., and C. Riddell (2008), "Education, credentials and immigrant earnings", Canadian Journal of Economics, vol. 4(1), pp. 186-216 
Frank, K. and F. Hou (2013), “Cultural Influences Across Time and Space: Do Source-country Gender Roles Affect Immigrant Women’s Paid and Unpaid Labour Activity?” Statistics Canada Analytical Studies Branch Research Paper Series \#349

Friedberg R (2000) You Can’t Take it With You: Immigrant Assimilation and the Portability of Human Capital. Journal of Labor Economics 18: 221-51

Imai, S., D. Stacey and C. Warman (2011) "From Engineer to Taxi Driver? Occupational Skills and the Economic Outcomes of Immigrants," Working Papers 1275, Queen's University,

Ingram, B. and G. Neumann (2006) “The returns to skill.” Labour Economics 13 (1):35-59

Kim, S. (2013) "Wage Mobility of Foreign-Born Workers in the United States”, J. Human Resources, vol. 48( 3), pp. 628-658

Kim, S., and Varanasi, N. (2010). Labor Supply of Married Women in Credit Constrained Households: Theory and Evidence”, Working Papers UWEC-2010-01, University of Washington.

Lewis, P. (ed.) (2009) Ethnologue: Languages of the World, Sixteenth edition. Dallas, Tex.: SIL International. Online version: http://www.ethnologue.com/.

Long, J.E. (1980), “The Effect of Americanization on Earnings: Some Evidence for Women”, Journal of Political Economy 88, pp620-29.

Meng, X. and Gregory, R. (2005) “Intermarriage and the Economic Assimilation of Immigrants” Journal of Labor Economics 23(1) pp.135-75.

Picot, G. and F. Hou (2009) "The Effect of Immigrant Selection and the IT Bust on the Entry Earnings of Immigrants” CLSRN WP \#29

Poletaev, Maxim and Chris Robinson. 2008. "Human capital specificity: Evidence form the Dictionary of Occupational Titles and Displaced Worker Surveys, 1984-2000.” Journal of Labor Economics 26 (3):387-420.

Schoeni R (1998) Labour Market Assimilation of Immigrant Women. Industrial and Labor Relations Review 51: 483-504

Sweetman, Arthur \& Warman, Casey, 2009. "Temporary Foreign Workers and Former International Students as a Source of Permanent Immigration," CLSRN Working Papers 2009-34,

Worswick, C.(1996) “Immigrant Families in the Canadian Labor Market” Canadian Public Policy 22(4): 378-96.

Worswick, C. (1999) “Credit constraints and the labour supply of immigrant families in Canada”, Canadian Journal of Economics, vol.32 (1), pp. 152-170 
Table 1. Sample Summary Statistics of women (18-45). Census 1991-2006

\begin{tabular}{|c|c|c|c|c|c|}
\hline & & \multicolumn{2}{|c|}{ Canadian born } & \multicolumn{2}{|c|}{ Immigrant } \\
\hline & & NB partner & $\begin{array}{c}\text { Immigrant } \\
\text { partner }\end{array}$ & NB partner & $\begin{array}{c}\text { Immigrant } \\
\text { partner }\end{array}$ \\
\hline \multicolumn{6}{|c|}{ Women Characteristics } \\
\hline \multirow[t]{2}{*}{ Age } & & 35 & 35 & 36 & 36 \\
\hline & High S. or less & 0.46 & 0.40 & 0.32 & 0.45 \\
\hline \multirow{3}{*}{ Education } & Non-university & 0.34 & 0.31 & 0.30 & 0.22 \\
\hline & Bachelor & 0.17 & 0.23 & 0.29 & 0.26 \\
\hline & Graduate & 0.03 & 0.05 & 0.09 & 0.08 \\
\hline \multicolumn{2}{|c|}{ Hours of Work } & 24.6 & 25.4 & 23.0 & 21.3 \\
\hline \multicolumn{2}{|c|}{ Labour Force Participation } & 0.81 & 0.82 & 0.76 & 0.72 \\
\hline & Social & 0.24 & 0.38 & 0.300 & -0.09 \\
\hline & Motor & -0.34 & -0.46 & -0.38 & -0.12 \\
\hline \multirow[t]{4}{*}{ Skills } & Strength & -0.30 & -0.43 & -0.32 & -0.12 \\
\hline & Quantitative & 0.06 & 0.18 & 0.12 & -0.12 \\
\hline & Visual & -0.35 & -0.42 & -0.37 & -0.28 \\
\hline & 1 & 1.00 & 1.00 & 0.63 & 0.41 \\
\hline \multirow{4}{*}{$\begin{array}{l}\text { Linguistic } \\
\text { proximity }\end{array}$} & 0.7 & & & 0.11 & 0.15 \\
\hline & $0.45-0.25$ & & & 0.09 & 0.03 \\
\hline & 0.10 & & & 0.08 & 0.18 \\
\hline & 0 & & & 0.10 & 0.23 \\
\hline \multicolumn{6}{|c|}{ Husband Characteristics } \\
\hline \multirow[t]{2}{*}{ Age } & & 37 & 40 & 40 & 40 \\
\hline & High S. or less & 0.45 & 0.37 & 0.33 & 0.38 \\
\hline \multirow[t]{3}{*}{ Education } & Non-university & 0.36 & 0.35 & 0.31 & 0.23 \\
\hline & Bachelor & 0.15 & 0.20 & 0.25 & 0.26 \\
\hline & Graduate & 0.04 & 0.08 & 0.11 & 0.13 \\
\hline \multicolumn{2}{|c|}{ Hours of Work } & 39.4 & 39.0 & 39.7 & 34.7 \\
\hline \multicolumn{2}{|c|}{ Labour Force Participation } & 0.95 & 0.94 & 0.94 & 0.89 \\
\hline \multicolumn{2}{|c|}{ Observations } & $74 \%$ & $6 \%$ & $3 \%$ & $17 \%$ \\
\hline \multicolumn{6}{|c|}{$\begin{array}{l}\text { Note: Linguistic proximity measured by Adsera and Pytlikova (2014) index. It equals } 1 \text { for same } \\
\text { language; } 0.7 \text { for sharing the } 4^{\text {th }} \text { level of linguistic tree; } 0.45 \text { for sharing up to } 3^{\text {rd }} \text { level; } 0.25 \text { for } \\
\text { sharing up to } 2^{\text {nd }} \text { level; } 0.1 \text { for } 1^{\text {st }} \text { level and } 0 \text { for none. Immigrants arriving at age } 18 \text { or older }\end{array}$} \\
\hline
\end{tabular}


Table 2.0dds ratio of the labour force participation of married immigrant women *

\begin{tabular}{|c|c|c|c|c|c|}
\hline & \multirow[b]{2}{*}{ Years in Canada } & \multicolumn{2}{|c|}{ All women } & \multicolumn{2}{|c|}{ University-educated women } \\
\hline & & NB husband & IMM husband & NB husband & IMM husband \\
\hline \multirow[t]{8}{*}{1991 Cohort } & 5 & 0.506 & 0.606 & 0.401 & 0.421 \\
\hline & & $(0.000)$ & $(0.000)$ & $(0.000)$ & $(0.000)$ \\
\hline & 10 & 0.707 & 0.736 & 0.592 & 0.509 \\
\hline & & $(0.000)$ & $(0.000)$ & $(0.000)$ & $(0.000)$ \\
\hline & 15 & 0.791 & 0.891 & 0.798 & 0.684 \\
\hline & & $(0.000)$ & $(0.041)$ & $(0.012)$ & $(0.041)$ \\
\hline & 20 & 0.875 & 0.910 & 0.684 & 0.833 \\
\hline & & $(0.021)$ & $(0.002)$ & $(0.021)$ & $(0.002)$ \\
\hline \multirow[t]{6}{*}{1996 Cohort } & 5 & 0.464 & 0.346 & 0.345 & 0.240 \\
\hline & & $(0.000)$ & $(0.000)$ & $(0.000)$ & $(0.000)$ \\
\hline & 10 & 0.673 & 0.651 & 0.579 & 0.527 \\
\hline & & $(0.000)$ & $(0.000)$ & $(0.000)$ & $(0.000)$ \\
\hline & 15 & 0.755 & 0.737 & 0.708 & 0.721 \\
\hline & & $(0.000)$ & $(0.000)$ & $(0.000)$ & $(0.000)$ \\
\hline \multirow[t]{4}{*}{2001 Cohort } & 5 & 0.394 & 0.269 & 0.333 & 0.215 \\
\hline & & $(0.000)$ & $(0.000)$ & $(0.000)$ & $(0.000)$ \\
\hline & 10 & 0.566 & 0.508 & 0.560 & 0.506 \\
\hline & & $(0.000)$ & $(0.000)$ & $(0.000)$ & $(0.000)$ \\
\hline \multirow[t]{2}{*}{2006 Cohort } & 5 & 0.365 & 0.271 & 0.325 & 0.254 \\
\hline & & $(0.000)$ & $(0.000)$ & $(0.000)$ & $(0.000)$ \\
\hline Observations & & \multicolumn{2}{|c|}{828,650} & \multicolumn{2}{|c|}{226,230} \\
\hline
\end{tabular}

All specifications include arrival cohort-time effects for immigrants and their spouses - as in equation (1) - plus controls for woman's age and age squared, education, location and survey year, husband's wage, number of children before migration, number of children 0-5 in the household and number of children 6-14, age at first birth and indicators for linguistic proximity to English. P-values in parenthesis.

* The sample is restricted to married women 18-45 years of age. Immigrants are adults (18 years or older) at arrival. 
Table 3.Odds ratio of the labour force participation of married immigrant women* (P-values)

\begin{tabular}{|c|c|c|c|c|c|c|c|c|c|}
\hline & & \multicolumn{4}{|c|}{ Low-Skill Jobs } & \multicolumn{4}{|c|}{ Low-Skill Jobs (University-educated women) } \\
\hline & \multirow[b]{2}{*}{ YSM } & \multicolumn{2}{|c|}{ Analytical (a) } & \multicolumn{2}{|c|}{ Strength (b) } & \multicolumn{2}{|c|}{ Analytical (a) } & \multicolumn{2}{|c|}{ Strength (b) } \\
\hline & & $\begin{array}{c}\text { NB } \\
\text { husband }\end{array}$ & $\begin{array}{c}\text { IMM } \\
\text { husband }\end{array}$ & $\begin{array}{c}\text { NB } \\
\text { husband }\end{array}$ & $\begin{array}{c}\text { IMM } \\
\text { husband }\end{array}$ & NB husband & $\begin{array}{c}\text { IMM } \\
\text { husband }\end{array}$ & $\begin{array}{c}\text { NB } \\
\text { husband }\end{array}$ & $\begin{array}{c}\text { IMM } \\
\text { husband }\end{array}$ \\
\hline \multirow[t]{8}{*}{1991 Cohort } & 5 & 1.145 & 1.141 & 1.040 & 1.481 & 2.046 & 2.842 & 1.291 & 1.749 \\
\hline & & $(0.011)$ & $(0.000)$ & $(0.400)$ & $(0.000)$ & $(0.000)$ & $(0.000)$ & $(0.003)$ & $(0.000)$ \\
\hline & 10 & 1.244 & 1.409 & 1.097 & 1.478 & 1.623 & 2.340 & 1.416 & 1.589 \\
\hline & & $(0.000)$ & $(0.000)$ & $(0.035)$ & $(0.000)$ & $(0.000)$ & $(0.000)$ & $(0.000)$ & $(0.000)$ \\
\hline & 15 & 1.087 & 1.691 & 1.171 & 1.550 & 1.858 & 2.978 & 1.243 & 1.501 \\
\hline & & $(0.130)$ & $(0.000)$ & $(0.001)$ & $(0.000)$ & $(0.000)$ & $(0.000)$ & $(0.016)$ & $(0.000)$ \\
\hline & 20 & 1.185 & 1.863 & 1.169 & 1.771 & 1.642 & 3.356 & 1.069 & 1.696 \\
\hline & & $(0.007)$ & $(0.000)$ & (0.005) & $(0.000)$ & $(0.000)$ & $(0.000)$ & $(0.522)$ & $(0.000)$ \\
\hline \multirow[t]{6}{*}{1996 Cohort } & 5 & 1.180 & 1.056 & 1.226 & 1.330 & 1.769 & 1.976 & 1.385 & 1.821 \\
\hline & & $(0.001)$ & (0.009) & $(0.000)$ & $(0.000)$ & $(0.000)$ & $(0.000)$ & $(0.000)$ & $(0.000)$ \\
\hline & 10 & 1.234 & 1.667 & 1.253 & 1.497 & 2.340 & 3.556 & 1.340 & 1.759 \\
\hline & & $(0.000)$ & $(0.000)$ & $(0.000)$ & $(0.000)$ & $(0.000)$ & $(0.000)$ & $(0.000)$ & $(0.000)$ \\
\hline & 15 & 1.279 & 1.854 & 1.125 & 1.664 & 2.778 & 3.744 & 1.211 & 1.776 \\
\hline & & $(0.003)$ & $(0.000)$ & (0.013) & $(0.000)$ & $(0.000)$ & $(0.000)$ & (0.015) & $(0.000)$ \\
\hline \multirow[t]{4}{*}{2001 Cohort } & 5 & 1.062 & 1.285 & 1.094 & 1.193 & 2.475 & 2.743 & 1.372 & 1.545 \\
\hline & & $(0.233)$ & $(0.000)$ & $(0.455)$ & $(0.000)$ & $(0.000)$ & $(0.000)$ & $(0.000)$ & $(0.000)$ \\
\hline & 10 & 1.066 & 1.622 & 1.044 & 1.376 & 2.264 & 3.455 & 1.104 & 1.541 \\
\hline & & $(0.261)$ & $(0.000)$ & $(0.366)$ & $(0.000)$ & $(0.000)$ & $(0.000)$ & (0.177) & $(0.000)$ \\
\hline \multirow[t]{2}{*}{2006 Cohort } & 5 & 1.168 & 1.597 & 1.041 & 1.321 & 2.521 & 3.897 & 1.136 & 1.682 \\
\hline & & $(0.001)$ & $(0.000)$ & (0.314) & $(0.000)$ & $(0.000)$ & $(0.000)$ & $(0.034)$ & (0.000) \\
\hline Observations & & \multicolumn{2}{|c|}{828,650} & \multicolumn{2}{|c|}{828,650} & \multicolumn{2}{|c|}{226,230} & \multicolumn{2}{|c|}{226,230} \\
\hline
\end{tabular}

All specifications include arrival cohort-time effects for immigrants and their spouses - as in equation (1) - plus controls for woman's age and age squared, education, location and survey year, husband's wage, number of children before migration, number of children 0-5 in the household and number of children 6-14, age at first birth and indicators for linguistic proximity to English. (a) Indicates participation in a job requiring low levels of analytical skills-job at the bottom $25 \%$ of the analytical skill distribution) (b) Indicates participation in a job requiring high levels of strength skills - job at the top $25 \%$ of the strength skill distribution)

* The sample is restricted to married women 18-45 years of age. Immigrants are adults (18 years or older) at arrival. 


\begin{tabular}{|c|c|c|c|c|c|c|}
\hline \multirow[b]{3}{*}{ Cohort } & \multicolumn{6}{|c|}{$\begin{array}{l}\text { Table 4. Weekly wages of immigrant women with immigrant partners } \\
\text { (relative to native-born women with NB partners) }\end{array}$} \\
\hline & \multirow[b]{2}{*}{ YSM } & \multicolumn{2}{|c|}{ All } & \multirow{2}{*}{$\begin{array}{l}\text { Heckman } \\
\text { (3) }\end{array}$} & \multirow{2}{*}{$\begin{array}{l}\text { Non-university } \\
\text { (4) }\end{array}$} & \multirow{2}{*}{$\begin{array}{l}\text { University } \\
\qquad \text { (5) }\end{array}$} \\
\hline & & (1) & $(2)$ & & & \\
\hline \multirow[t]{8}{*}{1991} & 5 & -0.220 & -0.164 & -0.109 & -0.100 & -0.303 \\
\hline & & $(0.000)$ & $(0.000)$ & $(0.000)$ & $(0.000)$ & $(0.000)$ \\
\hline & 10 & -0.152 & -0.101 & -0.062 & -0.054 & -0.226 \\
\hline & & $(0.000)$ & $(0.000)$ & $(0.000)$ & $(0.000)$ & $(0.000)$ \\
\hline & 15 & -0.075 & -0.010 & -0.020 & 0.035 & -0.132 \\
\hline & & $(0.000)$ & $(0.336)$ & $(0.041)$ & (0.009) & $(0.000)$ \\
\hline & 20 & -0.069 & 0.004 & -0.013 & 0.037 & -0.065 \\
\hline & & (0.003) & $(0.701)$ & (0.229) & (0.009) & (0.001) \\
\hline \multirow[t]{6}{*}{1996} & 5 & -0.384 & -0.309 & -0.231 & -0.200 & -0.484 \\
\hline & & (0.000) & $(0.000)$ & $(0.000)$ & $(0.000)$ & $(0.000)$ \\
\hline & 10 & -0.215 & -0.136 & -0.081 & -0.097 & -0.199 \\
\hline & & $(0.000)$ & $(0.000)$ & $(0.000)$ & $(0.000)$ & $(0.000)$ \\
\hline & 15 & -0.140 & -0.059 & -0.056 & 0.002 & -0.151 \\
\hline & & $(0.000)$ & $(0.000)$ & $(0.000)$ & $(0.844)$ & $(0.000)$ \\
\hline \multirow[t]{4}{*}{2001} & 5 & -0.428 & -0.590 & -0.218 & -0.197 & -0.412 \\
\hline & & $(0.000)$ & $(0.000)$ & $(0.000)$ & $(0.000)$ & $(0.000)$ \\
\hline & 10 & -0.282 & -0.347 & -0.168 & -0.088 & -0.264 \\
\hline & & $(0.000)$ & $(0.000)$ & $(0.000)$ & $(0.000)$ & $(0.000)$ \\
\hline \multirow[t]{2}{*}{2006} & 5 & -0.543 & -0.214 & -0.346 & -0.226 & -0.468 \\
\hline & & $(0.000)$ & $(0.000)$ & $(0.000)$ & $(0.000)$ & $(0.000)$ \\
\hline \multicolumn{7}{|l|}{ LP Index } \\
\hline 0.00 & & $-0.095 * * *$ & $-0.053 * * *$ & $-0.064 * * *$ & $-0.028 * * *$ & $-0.103 * * *$ \\
\hline 0.10 & & $-0.086 * * *$ & $-0.091 * * *$ & $-0.084 * * *$ & $-0.072 * * *$ & $-0.152 * * *$ \\
\hline 0.25 & & 0.016 & 0.007 & 0.022 & -0.017 & 0.037 \\
\hline 0.45 & & $-0.041 * * *$ & $-0.060 * * *$ & $-0.062 * * *$ & $-0.078 * * *$ & $-0.048 * * *$ \\
\hline 0.70 & & $-0.006^{*}$ & $0.013 * *$ & 0.004 & 0.002 & $-0.022 * *$ \\
\hline Social & & & $0.086 * * *$ & $0.066^{* * *}$ & $0.074 * * *$ & $0.117 * * *$ \\
\hline Motor & & & $0.152 * * *$ & $0.116^{* * *}$ & $0.188 * * *$ & $0.042 * * *$ \\
\hline Visual & & & $-0.080 * * *$ & $-0.049 * * *$ & $-0.083 * * *$ & $-0.021 * * *$ \\
\hline Strength & & & $-0.128 * * *$ & $-0.098 * * *$ & $-0.171 * * *$ & $-0.019 * * *$ \\
\hline Quantitative & & & $0.119 * * *$ & $0.116^{* * *}$ & $0.105^{* * *}$ & $0.162 * * *$ \\
\hline
\end{tabular}

The sample is restricted to married women 18-45 years of age. Immigrants are adults (18 years or older) at arrival. Regressions include arrival cohort-time effects for immigrants and their spouses - as in equation (1) plus controls for woman's age and age squared, education, location, fertility and survey year. Model (3) estimates a two-step selection model where, in a first stage model, participation depends on the female/male ratio of labour force participation in the country of origin at the time the woman was 18 years old, and the number of children (coefficients shown in the appendix). Models (4) and (5) repeat specification (2) for the subsamples of university- and non-university educated women, respectively.

$\left({ }^{* *}\right)$ indicates the coefficient is significant at $1 \%,\left({ }^{* *}\right)$ at $5 \% ;\left(^{*}\right)$ at $10 \%$. 
Table 5. Effect of Linguistic Proximity (LP) and Educational attainment on Wages of Immigrant Women

\begin{tabular}{lccccc}
\hline & $\mathbf{L P}=\mathbf{0 . 7}$ & $\mathbf{L P}=\mathbf{0 . 4 5}$ & $\mathbf{L P}=\mathbf{0 . 2 5}$ & $\mathbf{L P}=\mathbf{0 . 1}$ & $\mathbf{L P}=\mathbf{0}$ \\
\hline Non university & 0.001 & $0.033^{* *}$ & $0.089 * * *$ & $-0.021^{* *}$ & $-0.046^{* * *}$ \\
University & $-0.056 * * *$ & $-0.060 * * *$ & -0.049 & $-0.184 * * *$ & $-0.114 * * *$ \\
& & & & & \\
\hline
\end{tabular}

Note: Figures in the table show wage differences relative to immigrants with $L P=1$ with similar education level. The estimated coefficient for university $0.466 * * *$ has to be added when comparing individuals with university education to those without it.

The regression includes arrival cohort-time effects for immigrants and their spouses - as in equation (1) - plus controls for woman's age and age squared, education, location, fertility, husband's wage, and survey year.

The sample is restricted to married women $18-45$ years of age. Immigrants are adults (18 years or older) at arrival.

$(* * *)$ indicates the coefficient is significant at $1 \%,(* *)$ at $5 \%$ 
Table 6. Skill mobility of married immigrant women (relative to native-born women with NB husbands) Analytical Mobility

\section{Strength Mobility}

\section{(1) All (2) University}

\begin{tabular}{|c|c|c|c|c|c|c|c|c|c|}
\hline & YSM & $\begin{array}{c}\text { NB } \\
\text { husband }\end{array}$ & $\begin{array}{l}\text { Immigrant } \\
\text { husband }\end{array}$ & $\begin{array}{c}\text { NB } \\
\text { husband }\end{array}$ & $\begin{array}{l}\text { Immigrant } \\
\text { husband }\end{array}$ & $\begin{array}{c}\text { NB } \\
\text { husband }\end{array}$ & $\begin{array}{l}\text { Immigrant } \\
\text { husband }\end{array}$ & $\begin{array}{c}\text { NB } \\
\text { husband }\end{array}$ & $\begin{array}{l}\text { Immigrant } \\
\text { husband }\end{array}$ \\
\hline \multirow[t]{4}{*}{1991} & 5 & $\begin{array}{c}-0.163 \\
(0.000)\end{array}$ & $\begin{array}{l}-0.263 \\
(0.000)\end{array}$ & $\begin{array}{l}-0.224 \\
(0.000)\end{array}$ & $\begin{array}{l}-0.390 \\
(0.000)\end{array}$ & $\begin{array}{c}0.108 \\
(0.000)\end{array}$ & $\begin{array}{c}0.166 \\
(0.000)\end{array}$ & $\begin{array}{c}0.165 \\
(0.000)\end{array}$ & $\begin{array}{c}0.224 \\
(0.000)\end{array}$ \\
\hline & 10 & $\begin{array}{c}-0.166 \\
(0.000)\end{array}$ & $\begin{array}{l}-0.242 \\
(0.000)\end{array}$ & $\begin{array}{l}-0.189 \\
(0.000)\end{array}$ & $\begin{array}{l}-0.332 \\
(0.000)\end{array}$ & $\begin{array}{c}0.095 \\
(0.000)\end{array}$ & $\begin{array}{c}0.165 \\
(0.000)\end{array}$ & $\begin{array}{c}0.187 \\
(0.000)\end{array}$ & $\begin{array}{c}0.194 \\
(0.000)\end{array}$ \\
\hline & 15 & $\begin{array}{l}-0.059 \\
(0.000)\end{array}$ & $\begin{array}{c}-0.274 \\
(0.000)\end{array}$ & $\begin{array}{c}-0.097 \\
(0.000)\end{array}$ & $\begin{array}{l}-0.241 \\
(0.000)\end{array}$ & $\begin{array}{c}0.077 \\
(0.000)\end{array}$ & $\begin{array}{c}0.167 \\
(0.000)\end{array}$ & $\begin{array}{c}0.073 \\
(0.011)\end{array}$ & $\begin{array}{c}0.069 \\
(0.000)\end{array}$ \\
\hline & 20 & $\begin{array}{l}-0.075 \\
(0.000)\end{array}$ & $\begin{array}{l}-0.307 \\
(0.000)\end{array}$ & $\begin{array}{l}-0.105 \\
(0.000)\end{array}$ & $\begin{array}{l}-0.295 \\
(0.000)\end{array}$ & $\begin{array}{c}0.053 \\
(0.000)\end{array}$ & $\begin{array}{c}0.246 \\
(0.000)\end{array}$ & $\begin{array}{l}-0.032 \\
(0.035)\end{array}$ & $\begin{array}{c}0.107 \\
(0.000)\end{array}$ \\
\hline \multirow[t]{3}{*}{1996} & 5 & $\begin{array}{c}-0.249 \\
(0.000)\end{array}$ & $\begin{array}{l}-0.307 \\
(0.000)\end{array}$ & $\begin{array}{l}-0.317 \\
(0.000)\end{array}$ & $\begin{array}{l}-0.424 \\
(0.000)\end{array}$ & $\begin{array}{c}0.171 \\
(0.000)\end{array}$ & $\begin{array}{c}0.217 \\
(0.000)\end{array}$ & $\begin{array}{c}0.228 \\
(0.000)\end{array}$ & $\begin{array}{c}0.282 \\
(0.000)\end{array}$ \\
\hline & 10 & $\begin{array}{l}-0.180 \\
(0.000)\end{array}$ & $\begin{array}{l}-0.309 \\
(0.000)\end{array}$ & $\begin{array}{l}-0.226 \\
(0.000)\end{array}$ & $\begin{array}{l}-0.348 \\
(0.000)\end{array}$ & $\begin{array}{c}0.104 \\
(0.000)\end{array}$ & $\begin{array}{c}0.205 \\
(0.000)\end{array}$ & $\begin{array}{c}0.066 \\
(0.009)\end{array}$ & $\begin{array}{c}0.131 \\
(0.000)\end{array}$ \\
\hline & 15 & $\begin{array}{l}-0.156 \\
(0.000)\end{array}$ & $\begin{array}{l}-0.325 \\
(0.000)\end{array}$ & $\begin{array}{l}-0.237 \\
(0.000)\end{array}$ & $\begin{array}{l}-0.345 \\
(0.000)\end{array}$ & $\begin{array}{c}0.045 \\
(0.000)\end{array}$ & $\begin{array}{c}0.242 \\
(0.000)\end{array}$ & $\begin{array}{c}0.050 \\
(0.051)\end{array}$ & $\begin{array}{c}0.148 \\
(0.000)\end{array}$ \\
\hline \multirow[t]{2}{*}{2001} & 5 & $\begin{array}{l}-0.198 \\
(0.000)\end{array}$ & $\begin{array}{l}-0.321 \\
(0.000)\end{array}$ & $\begin{array}{l}-0.293 \\
(0.000)\end{array}$ & $\begin{array}{l}-0.380 \\
(0.000)\end{array}$ & $\begin{array}{c}0.066 \\
(0.000)\end{array}$ & $\begin{array}{c}0.106 \\
(0.000)\end{array}$ & $\begin{array}{c}0.065 \\
(0.008)\end{array}$ & $\begin{array}{c}0.078 \\
(0.000)\end{array}$ \\
\hline & 10 & $\begin{array}{l}-0.135 \\
(0.000)\end{array}$ & $\begin{array}{l}-0.281 \\
(0.000)\end{array}$ & $\begin{array}{l}-0.233 \\
(0.000)\end{array}$ & $\begin{array}{l}-0.343 \\
(0.000)\end{array}$ & $\begin{array}{c}0.011 \\
(0.000)\end{array}$ & $\begin{array}{c}0.121 \\
(0.000)\end{array}$ & $\begin{array}{c}-0.012 \\
(0.595)\end{array}$ & $\begin{array}{c}0.086 \\
(0.000)\end{array}$ \\
\hline 2006 & 5 & $\begin{array}{l}-0.273 \\
(0.000)\end{array}$ & $\begin{array}{l}-0.458 \\
(0.000)\end{array}$ & $\begin{array}{c}-0.364 \\
(0.000)\end{array}$ & $\begin{array}{l}-0.574 \\
(0.000)\end{array}$ & $\begin{array}{c}0.053 \\
(0.000)\end{array}$ & $\begin{array}{c}0.188 \\
(0.000)\end{array}$ & $\begin{array}{c}0.055 \\
(0.006)\end{array}$ & $\begin{array}{c}0.207 \\
(0.000)\end{array}$ \\
\hline
\end{tabular}

The sample is restricted to married women $18-45$ years of age. Immigrants are adults at arrival

Regression includes cohort-time effects for immigrants and their spouses - as in equation (1) - plus controls for woman's age and age squared, education, linguistic proximity, location, fertility and survey year. Coefficient represented in figures 5 and 6

$(* * *)$ indicates the coefficient is significant at $1 \%$. YSM stands for "years since migration" 
Figure 1. Distribution of analytical (quantitative) and physical strength skills in jobs held by married women by family type
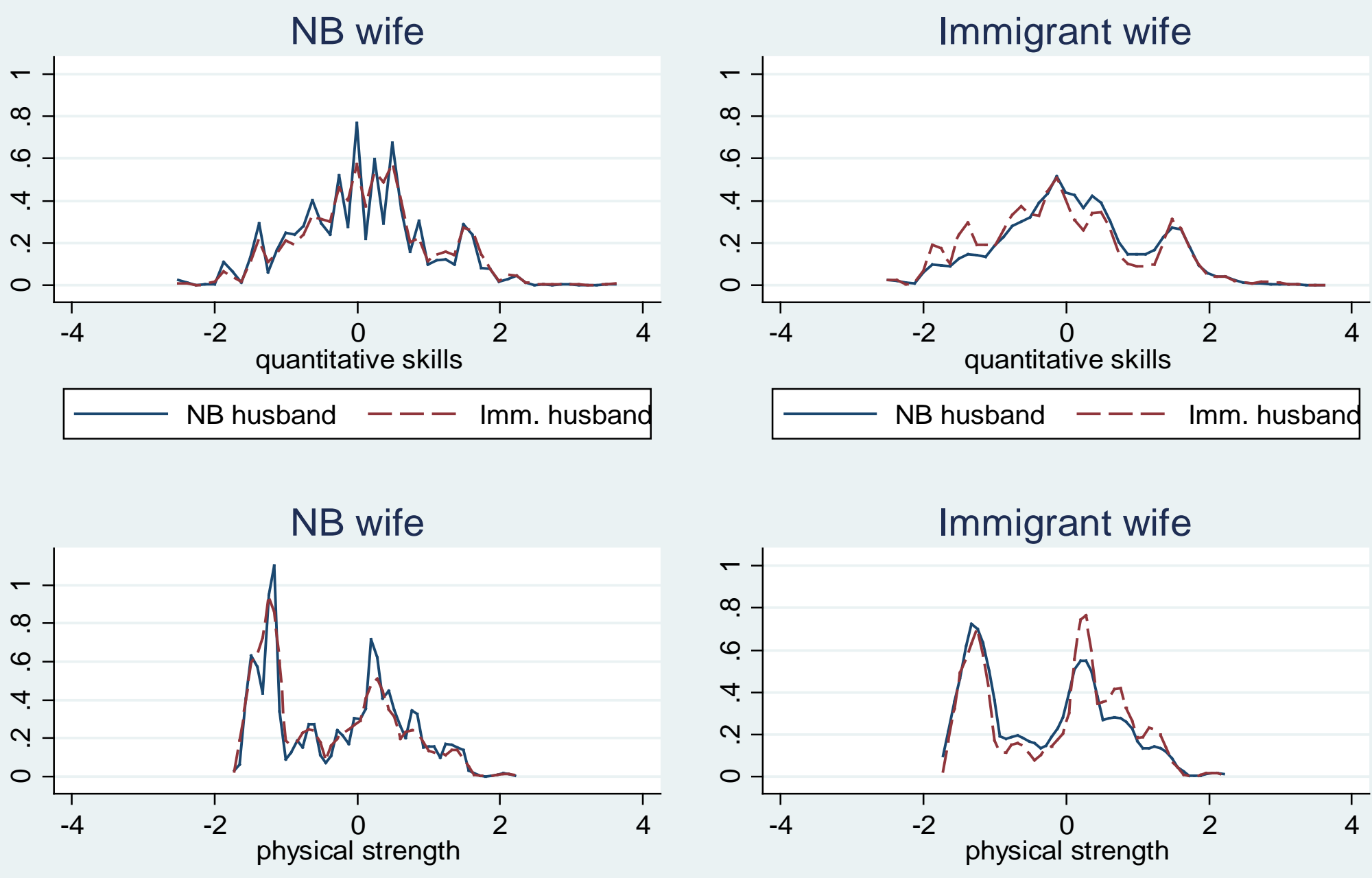

NB husband --- Imm. husband

NB husband --- Imm. husband 
Figure 2. Distribution of weekly wages of married women by immigrant status of husband
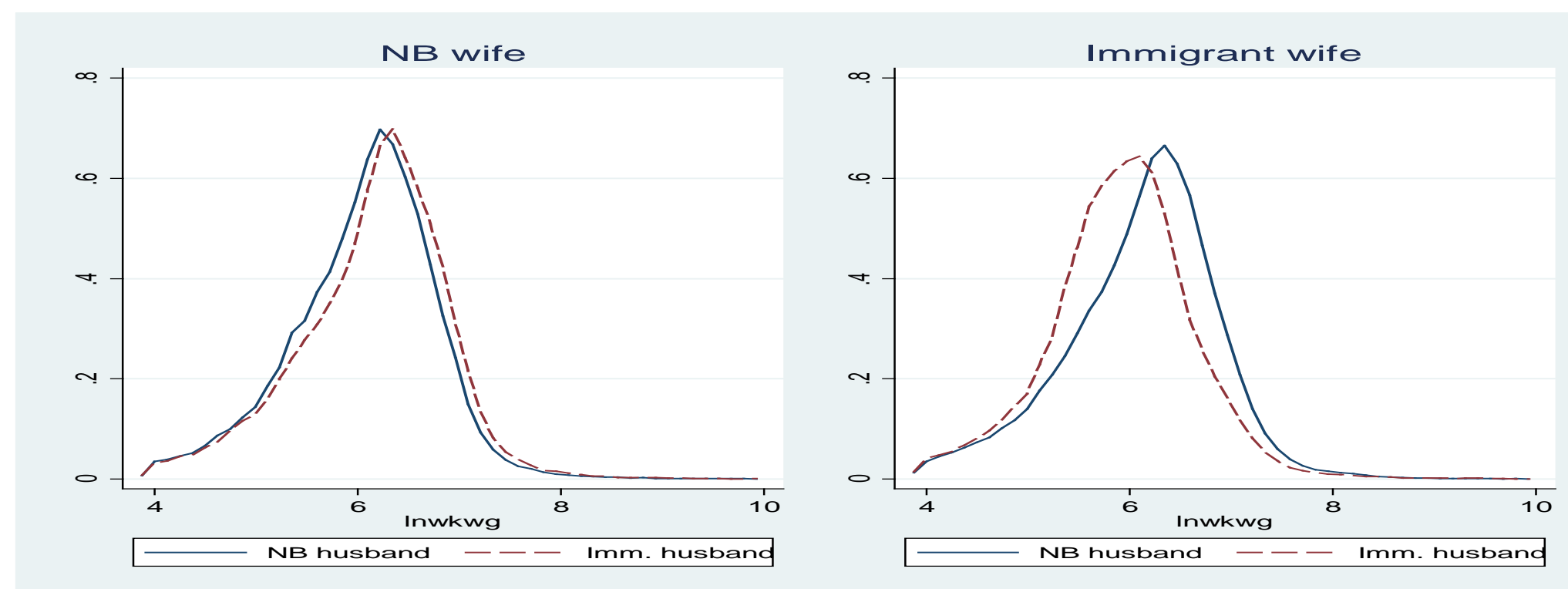
Figure 3. Odds ratio of participation of university-educated immigrant women with immigrant-husbands by type of job, relative to university-educated native women with native-born husbands.

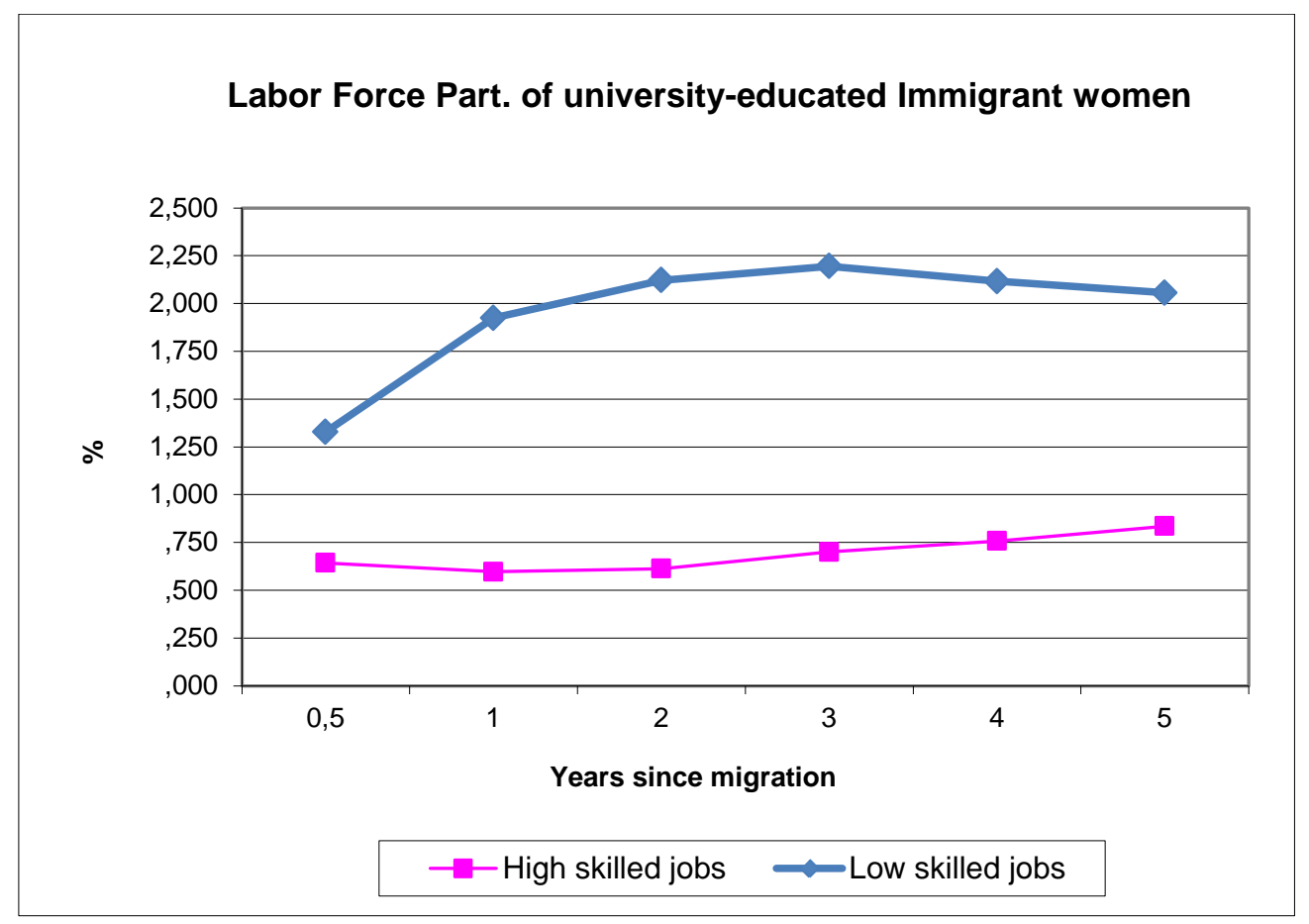

Source: Author's calculations using Canadian census 1991-2006. For low skills, the dependent variable is an indicator equal to 1 if a woman participates in a job requiring skills either at the bottom quartile of the analytical distribution or at the top quartile of the strength distribution. For high skills, the definition is the reverse. 
Figure 4. Wage assimilation of married immigrant women in immigrant couples relative to native-born women, by educational attainment of women.

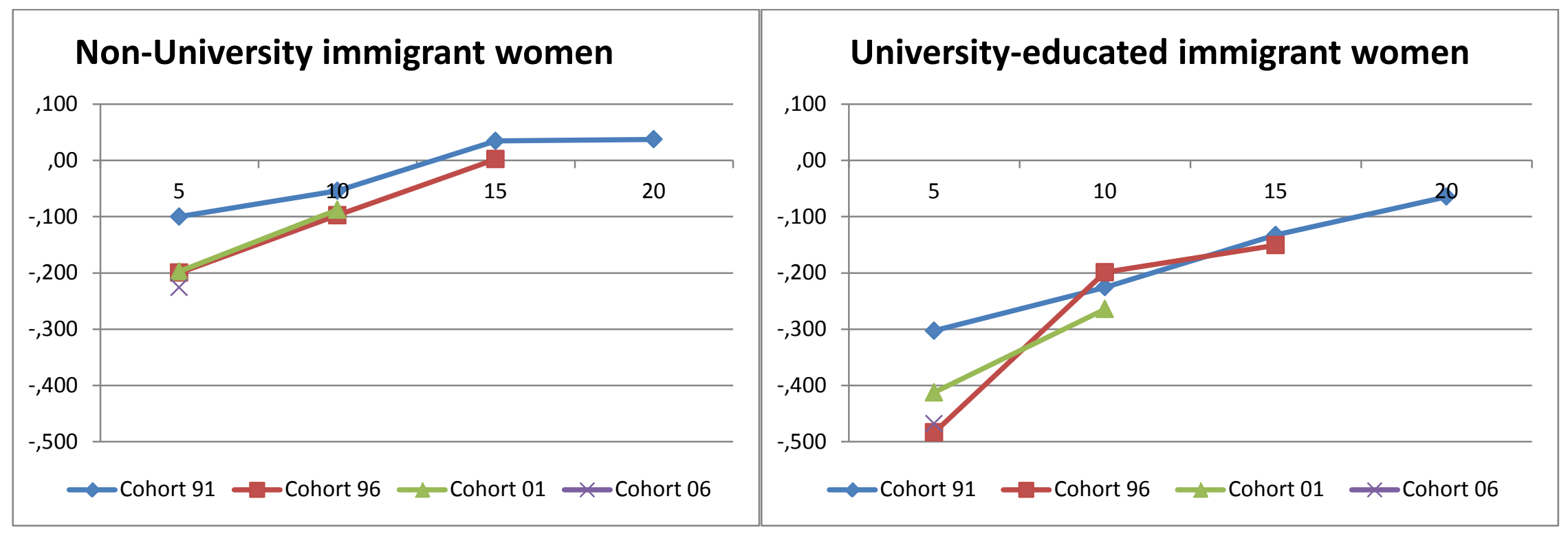


Figure 5 (a). Analytical skill mobility of married immigrant women, by cohort and family type (see Table 6)
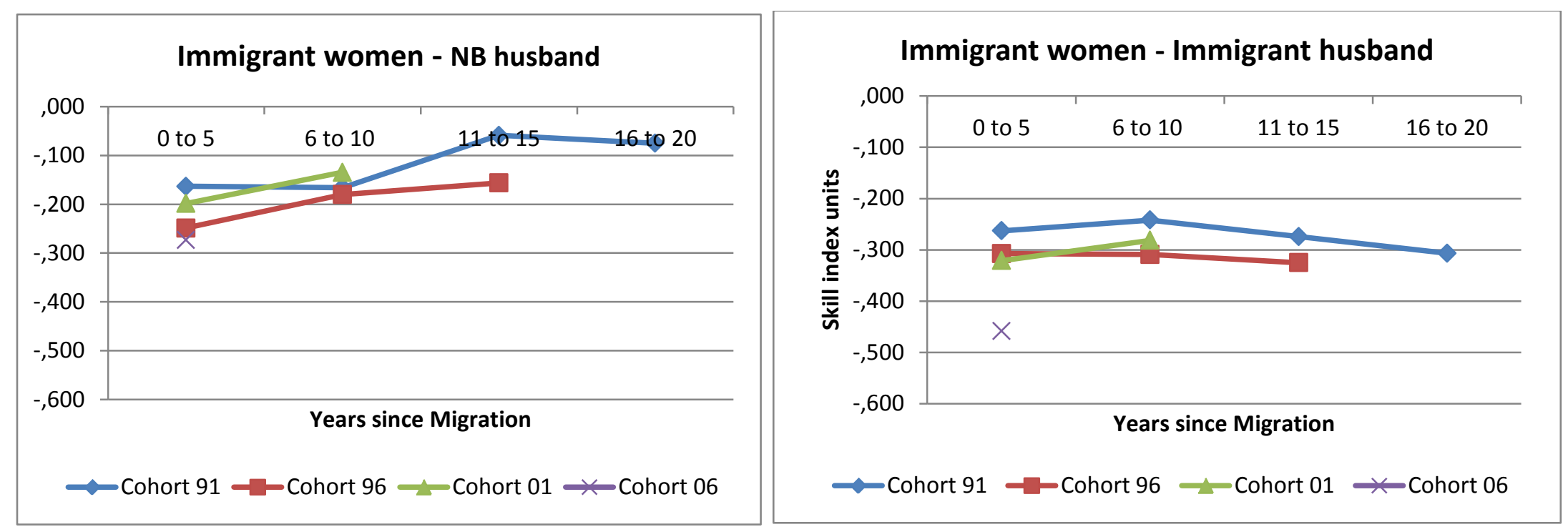

Figure 5 (b). Analytical skill mobility of university-educated married immigrant women, by cohort and family type. (see Table 6)
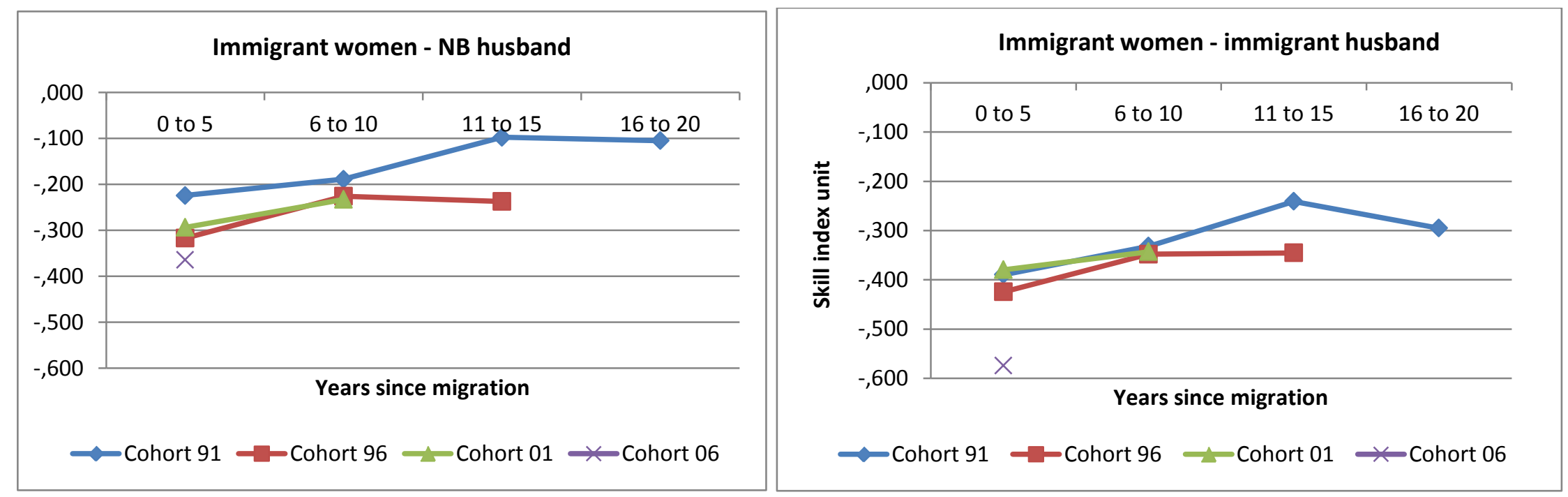
Figure 6 (a). Physical strength skill mobility of married immigrant women, by cohort and family type (see Table 6)
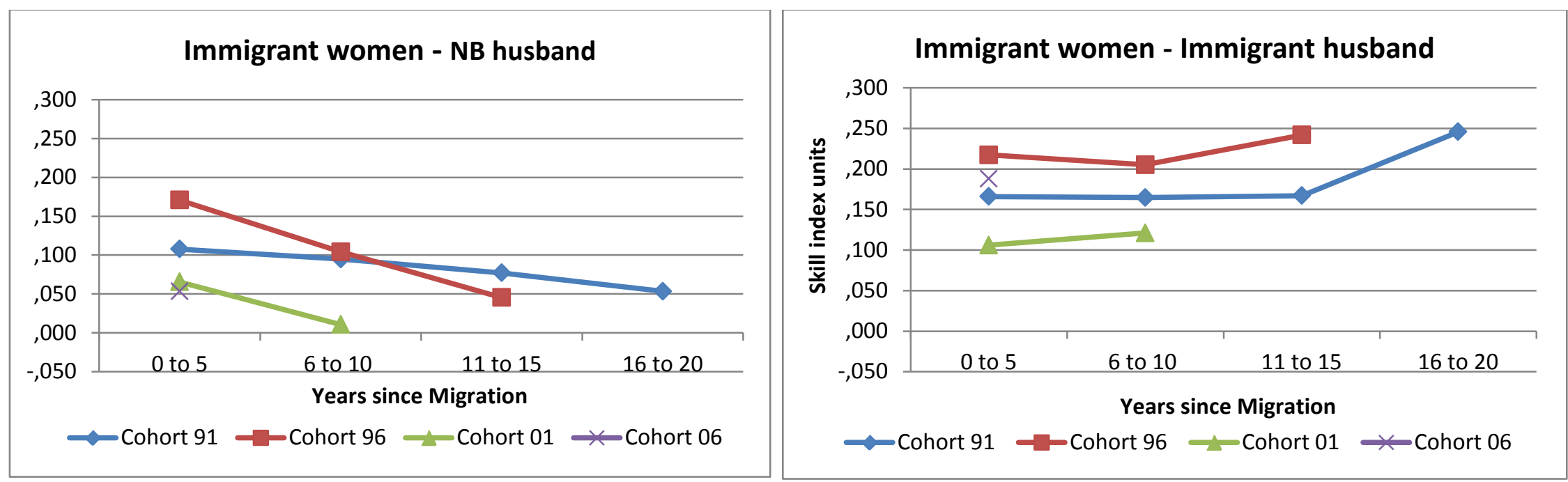

Figure 6 (b). Physical strength skill mobility of university-educated married immigrant women, by cohort and family type. (see Table 6)
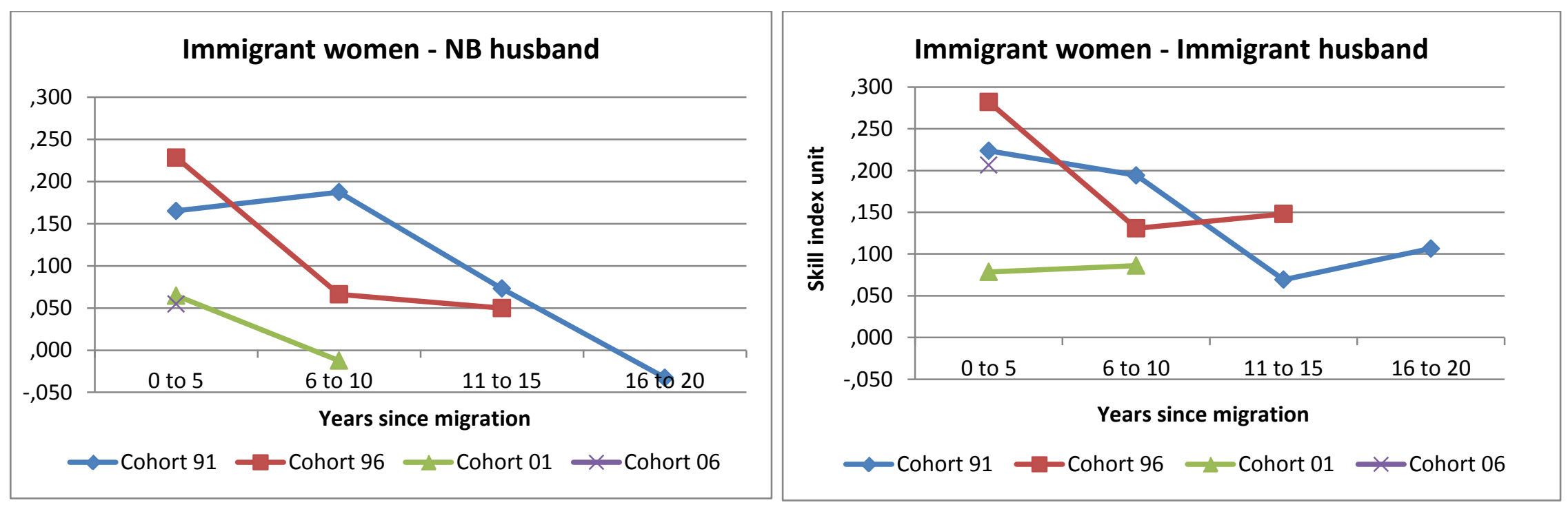
Figure 7 (a). Wage assimilation of immigrant men by wive’s labor force participation.
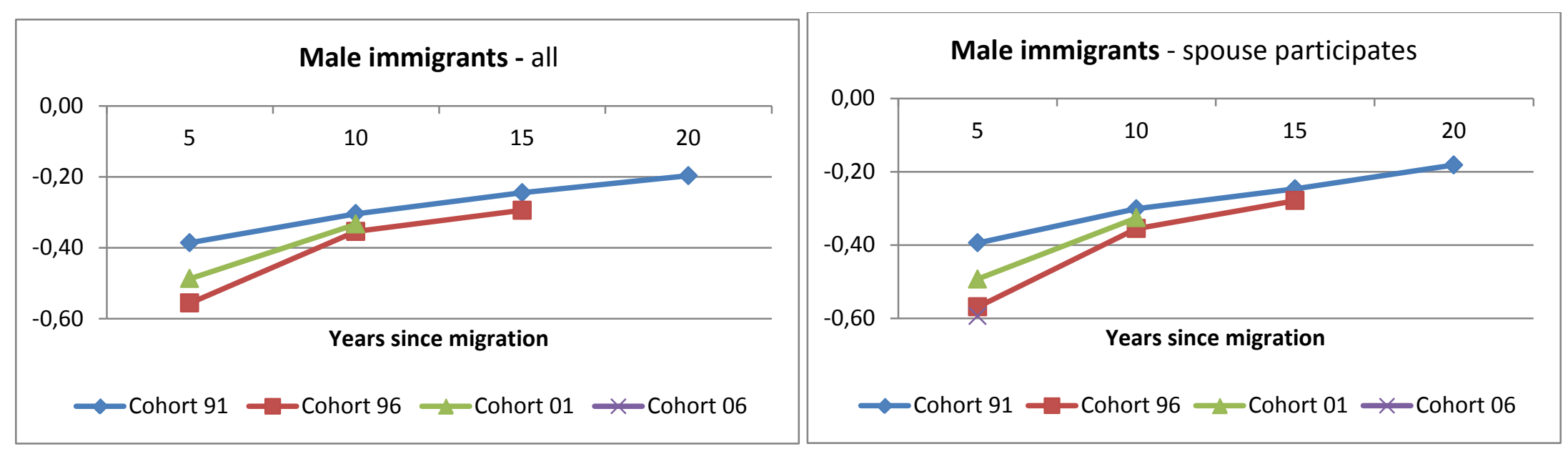

Figure 7 (b). Analytical skill mobility of immigrant men by wive’s labor force participation.

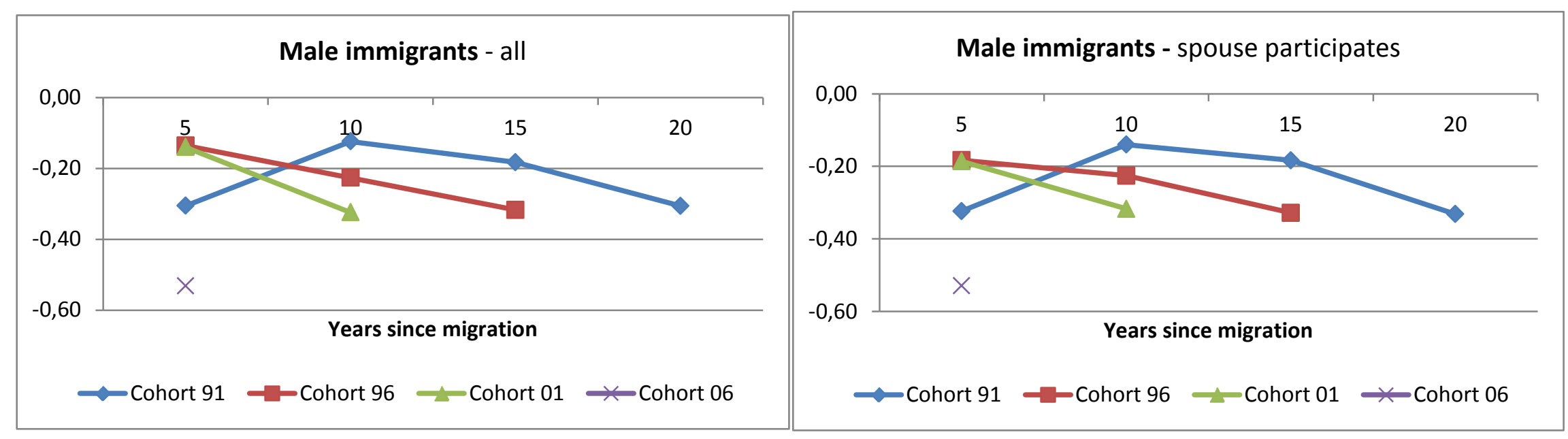


Appendix

Table 1. First Stage estimates for wage equation in column (3), table 4

LFP

Number of children

Gender Labour Force Ratio at home at immigration

Children before migration

lambda (SE)

$\begin{array}{cc}\text { Coefficient } & \text { P-value } \\ -0.13 & 0.00 \\ 0.17 & 0.00 \\ -0.19 & 0.00 \\ & \\ -0.88 & \\ (0.004) & \end{array}$

36218

0.000 
Figure 1. Immigrant women labour force participation in low skilled jobs (quantitative) by husband education
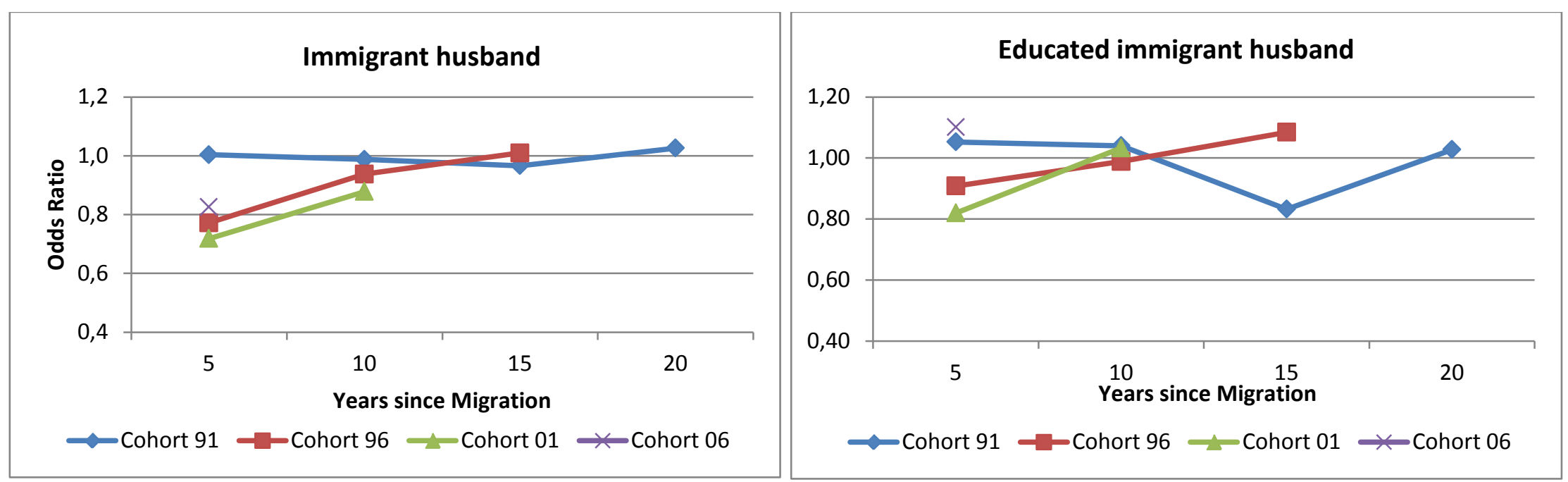

Figure 2. Immigrant women quantitative skill mobility by cohort and family type. Educated husbands
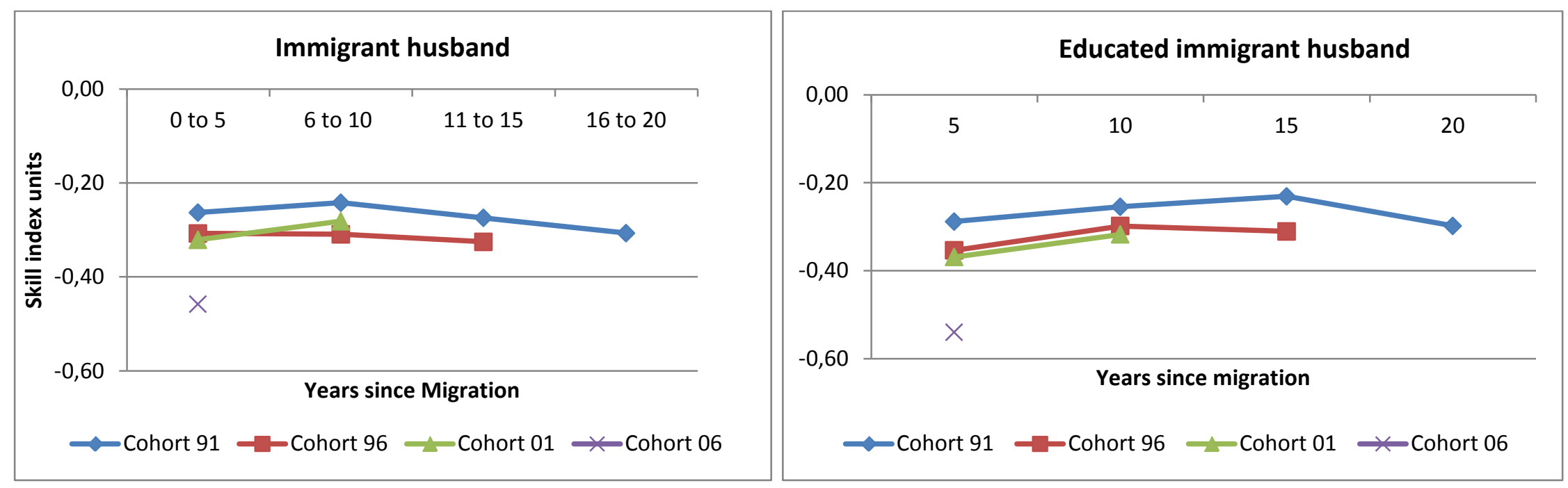